\title{
Alteration of payload in extracellular vesicles by crosstalk with mesenchymal stem cells from different origin
}

\author{
Dong Jun Park ${ }^{1,2,3^{*}}$ (D) Jeong-Eun Park ${ }^{1,2}$, Tae Hoon Kong ${ }^{1,2}$ and Young Joon Seo ${ }^{1,2,4^{*}}$ (i)
}

\begin{abstract}
Background: The application of extracellular vesicles (EVs) derived from mesenchymal stem cells (MSCs) requires customized materials to target disease or cell damage. We hypothesized that EVs exert different inflammatory effects on one recipient cell, although stem cells of different origins in humans have similar payloads.

Results: Here, the payload of EVs released by crosstalk between MSCs and human middle ear epithelial cells (HMEECs) extracted from adipose tissue, bone marrow and tonsils significantly increased the level of anti-inflammatory factors. EVs derived from the co-culture medium decreased TNF- $a, C O X-2, I L-1 \beta$, and IL-6 levels to approximately zero within $3 \mathrm{~h}$ in HMEECs. Expression of miR-638 and amyloid- $\beta$ A4 precursor protein-binding family A member 2 was analyzed using microarrays and gene ontology analysis, respectively.
\end{abstract}

Conclusions: In conclusion, stem cells of different origins have different payloads through crosstalk with recipientspecific cells. Inducing specific factors in EVs by co-culture with MSCs could be valuable in regenerative medicine.

Keywords: Extracellular vesicles, Mesenchymal stem cell, Antiinflammation, Amyloid- $\beta$ A4 precursor protein-binding family A member 2, miR-638

\section{Background}

Otitis media $(\mathrm{OM})$ is one of the most common diseases affecting children [1]. Although acute OM may resolve spontaneously, oral antibiotics and corticosteroids are ineffective in the long-term treatment of recurrent and chronic OM. Bacterial resistance to antibiotics has become an emerging problem in many parts of the world. Researchers have focused on understanding the pathophysiology of $\mathrm{OM}$ as a replacement for antibiotic treatment, including the role of inflammatory mediators and ion homeostasis molecules [2]. Restoration of

\footnotetext{
*Correspondence: papapdj@gmail.com; okas2000@hanmail.net

1 Department of Otorhinolaryngology, Yonsei University Wonju College of Medicine, 20 Ilsan- ro, Wonju, Gangwon-do 26426, South Korea

${ }^{3}$ Department of Surgery, University of California San Diego, 212 Dickinson Street, MC 8236, San Diego, CA 92103, USA

Full list of author information is available at the end of the article
}

fluid homeostasis function in the middle ear epithelium could be a target for future treatment, similar to the role of the upper respiratory ciliated mucosa. The middle ear mucosa is a pseudostratified, ciliated columnar epithelium through the eustachian tube that continues to the respiratory tract. Stem cell-derived exosomes control inflammatory signaling within the airway through intercellular communication, as demonstrated by the transfer of suppressor of cytokine signaling 1 from macrophagederived exosomes to alveolar epithelial cells [3]. Human mesenchymal stem cell (hMSC)-derived extracellular vesicles (EVs) possess most of the anti-inflammatory and neuroprotective activities of MSCs in the respiratory epithelium $[4,5]$.

Therapeutics based on stem cell technology, including stem cell-derived EVs, have emerged in recent years and can treat what were otherwise considered incurable diseases in the field of cancer or cell regeneration 
[5]. Studies have also been proposed to find biomarkers in EVs for specific cancers [6]. Mesenchymal stem cells (MSCs) have been found to have different sources, such as the bone marrow, fat, urine, and tonsil; although they have the same phenotype, they are reported to have different internal payloads with various efficacies of treatments $[5,7]$. It has been found that tumor-derived EVs play a key role in crosstalk between malignant and transformed cells and the immune system and that cancer cells suppress immune surveillance [8]. In addition, stem cell-derived EVs are involved in crosstalk with surrounding cells during development and release their molecules to them $[9,10]$, and help the survival of surrounding cells through secretion via EVs of inflammatory, differentiation, and proliferation factors $[4,5]$.

EVs are a heterogeneous group of secreted membranous vesicles, including microvesicles, ectosomes, and exosomes [11]. They have become valuable biomarkers in liquid biopsies [12], and existing research has focused on their characterization in different cancer types [9]. When stem cells undergo autophagy through external stimulation, exocytosis is stimulated when intracellular multivesicular bodies (MVBs) increase, resulting in a large number of extracellular vesicles [13]. Furthermore, EVs are known to be released by a variety of human cells and are important mediators in the coordination of the immune response to maintain host homeostasis $[5,14]$. Upon different stimulation, EVs carry different combinations of nucleic acids, proteins, and lipids to other cells [15] and have been reported to be associated with certain pathological conditions, particularly microbial infections and cancer [16]. It has also been reported that the amount of EVs released following external stimulation increases with time [13]. The ability to block the transfer of tumor-derived EVs containing oncogenic messages, such as EGFR, into recipient cells is a potential antitumor strategy. A study showed that incubation of EVs from a cell line with heparin blocked their transfer into recipient cells [17].

In this study, we evaluated the anti-inflammatory effect of EVs derived from hMSCs extracted from the adipose tissue, bone marrow, and tonsils. MSCs derived from these sources contain several factors related to cell proliferation and inflammation-reducing substances [18-20], but miRNA or cytokine expression and efficacy by crosstalk with new recipient cells may differ [14, 21]. Various studies have reported the relief of inflammation in skin tissues and infected organs in animal models [22]. The current focus of anti-inflammatory studies using MSCderived EVs is to increase the payload of useful factors in EVs through discovery of factors through wound healing and mechanism research [23, 24]; there are reports that a calcium-dependent mechanism increases the release of
EVs from the cells [25]. However, the important aspect of MSC research is to observe the change in payload inside the MSC and understands its role in disease [21]. In this study, we profiled the factors related to anti-inflammatory activity in EVs derived from MSCs extracted from different origins, when co-cultured with human middle ear epithelial cells (HMEECs), which can cause OM [26]. Interestingly, the expression level of molecule payload and anti-inflammatory efficiency were different in EVs from MSCs derived from adipose tissue, bone marrow, and tonsils co-cultured with HMEECs. Therefore, we propose a technology to discover new miRNA candidates by profiling it to prove inflammation relief according to the change of EV payload by crosstalk between MSCs and target cells is altered. In addition, the technique, involving the co-culture condition, offers a new direction for MSC-derived EV research to cure diseases or cancer; studies on the mechanism underlying the crosstalk between donor and recipient cells are also needed.

\section{Materials and methods \\ Extraction of mesenchymal stem cells (MSCs) derived from adipose tissue, bone marrow, and tonsils}

The human adipose tissue, bone marrow, and tonsils were obtained from the iliac crest of patients who received transplantation treatment at the Wonju Severance Christian Hospital after obtaining their written consent (IRB number: CR320104). The extraction of adipose tissuederived MSCs was performed as described by Cho et al. [18]. Briefly, the tissue samples were washed twice with phosphate-buffered saline (PBS, D8537, Sigma-Aldrich, MA, USA) to remove blood cells and incubated with 200 $\mathrm{IU} / \mathrm{mL}$ collagenase (Thermo Fisher Scientific, Carlsbad, CA, USA) for $45 \mathrm{~min}$ at $37^{\circ} \mathrm{C}$. After incubation, the samples were centrifuged at $300 \times g$ for $7 \mathrm{~min}$, the supernatant was discarded, and the remaining pellets were resuspended in MEM-alpha (Hyclone, Logan, UT, USA) with $10 \%$ fetal bovine serum (FBS) (Gibco, Grand Island, NY, USA) and antibiotics (anti-anti, Thermo Fisher Scientific, Carlsbad, CA, USA). The cells were transferred to a culture plate and incubated in a humidified atmosphere of $95 \%$ air and $5 \% \mathrm{CO}_{2}$ at $37^{\circ} \mathrm{C}$.

To extract MSCs derived from the bone marrow, aspirates were collected into Vacutainers K2 EDTA (BD Biosciences, San Jose, CA, USA). The mononuclear cells were diluted 1:5 with PBS and separated by density gradient centrifugation at $435 \times g$ for $20 \mathrm{~min}$ at room temperature $\left(\mathrm{RT}, 25^{\circ} \mathrm{C}\right.$ ) using a Ficoll Hypaque (GE17-1440-02, Gibco, Grand Island, NY, USA) solution. The cell fractions were collected and cultured using MEM-alpha with $10 \%$ FBS and antibiotics at a seeding density of $5 \times 10^{3}$ cells per $\mathrm{cm}^{2}$. The plate was maintained at $37{ }^{\circ} \mathrm{C}$ in a humidified atmosphere containing $5 \% \mathrm{CO}_{2}$. To exchange 
the medium, the plate was washed with PBS to remove the non-adherent cells, and the medium was replaced. Upon reaching $70 \%$ confluence, the cells were passaged to $1 \times 10^{6}$ cells/plate.

Tonsil-derived MSCs were extracted as described by Bacic et al. [27]. The tonsil tissue was gently washed with ethanol and cut with surgical scissors on a plate. After washing with PBS, the tissue mixture was added to Falcon tubes and incubated with PBS, $200 \mathrm{IU} / \mathrm{mL}$ collagenase, and $10 \mu \mathrm{g} / \mathrm{mL}$ DNase (EN0525, Thermo Fisher Scientific, Carlsbad, CA, USA) at $37{ }^{\circ} \mathrm{C}$ in a water bath for $1 \mathrm{~h}$. After filtering the suspension using a cell strainer, the monocytes were isolated from the supernatant using Ficoll Hypaque density gradient centrifugation. The cell fractions were collected and cultured using MEM-alpha with $10 \%$ FBS and antibiotics at a seeding density of $5 \times 10^{3}$ cells per $\mathrm{cm}^{2}$.

\section{Flow cytometric analysis}

Flow cytometry was used to assess the immune profile of MSCs using the standard for MSCs, as described by the International Society for Cellular Therapy (ISCT) [28]. The cell surface markers were analyzed using a human MSC (hMSC) analysis kit (562245, BD Biosciences, San Jose, CA, USA). According to the manufacturer's instructions, the hMSC-positive cocktail (CD90 FITC, CD105 PerCP-Cy5.5, and CD73 APC) and PE hMSC negative cocktail (CD34, CD11b, CD19, CD45, and HLA-DR) were used as the positive and negative controls, respectively. As stated in this recommendation in the manufacturer's instructions, MSCs should be positive for CD73, CD90 and CD105, but negative for CD34, CD45, CD11b or CD14, CD19 or CD79 $\alpha$ and HLA-DR. Since MSCs are known to express numerous cell surface markers such as CD44, CD29, CD200, CD166, CD146, and CD271, we used CD44 as a representative in this study. The hMSC Positive Isotype Control Cocktail (mIgG1к FITC, mIgG1 $\kappa$ PerCP-Cy5.5, and mIgG1 к APC) and PE hMSC Negative Isotype Control Cocktail in the kit (mIgG1 $\kappa$ PE and mIgG2a $\mathrm{K}$ PE) were also used as an isotype control for the analysis. The samples were analyzed through flow cytometry using a FACS Aria3 flow cytometer (Becton Dickinson, San Jose, CA, USA). The data were analyzed using the FACS Diva software.

\section{Culture of human middle ear epithelial cells}

HMEECs were provided by Dr. David J. Lim (House Ear Institutes, Los Angeles, CA, USA). The cells were immortalized with the E6/E7 genes of the human papillomavirus [29] and cultured in Dulbecco's modified Eagle's medium (Lonza, MD, USA) and bronchial epithelial basal medium (Lonza, 1:1). The medium was changed every 3 days after washing with PBS. The cells were then humidified at $37{ }^{\circ} \mathrm{C}$ with $5 \% \mathrm{CO}_{2}$.

\section{Isolation of extracellular vesicles}

To obtain EVs, initial extraction was performed according to the MISEV guidelines as far as possible [30]. The cells were cultured in a serum-free environment for inducing EV expression, and analyzed EVs from the media by western blot and NTA. After centrifuging the cells and debris, the medium was collected and centrifuged at $2000 \times g$ for $30 \mathrm{~min}$, and the total exosome isolation reagent (4478359, Invitrogen, Grand Island, USA) was used according to the manufacturer's instructions. To purify EVs from the fractions, we centrifuged the fraction at $10,000 \times g$ for $1 \mathrm{~h}$ at $4{ }^{\circ} \mathrm{C}$ on the next day and added 200 $\mu \mathrm{L}$ of PBS to the sunk pellets to dissolve them. The samples were centrifuged at $22,000 \times g$ for $2 \mathrm{~h}$ at $4{ }^{\circ} \mathrm{C}$ using a table microcentrifuge (5424R, Eppendorf, Germany) to obtain high-purity EVs.

\section{Transwell study}

Co-culture conditions employed in this study were reported by Lu et al. [31]. One million MSCs were seeded into a transwell insert with a $0.4-\mu \mathrm{m}$ pore size (3401, Corning, NY, USA) consisting of a polycarbonate membrane. MSCs derived from adipose tissue, bone marrow, and tonsil were co-cultured with HMEECs in the inner well. In addition, HMEECs were seeded into the outer well. They were then carefully transferred and cultured in a $37{ }^{\circ} \mathrm{C}$ incubator with $5 \% \mathrm{CO}_{2}$ in a humidified atmosphere prior to the appropriate LPS treatment or isolation of EVs from the media.

\section{Cell viability assay}

Cell viability was measured using a cell counting kit according to the manufacturer's instructions (CCK-300, Seoul, Korea). The cells were seeded at $1 \times 10^{3}$ cells per well in a 96-well plate. After exposure to $1,5,10$, and $100 \mu \mathrm{g} / \mathrm{mL}$ LPS for different periods of time, CCK- 8 solution was added to each well and the plates were incubated for $4 \mathrm{~h}$ at $37{ }^{\circ} \mathrm{C}$. Cell viability was also measured after HMEECs were co-cultured with MSCs for $24 \mathrm{~h}$. The plate was mixed thoroughly using a shaker, and the optical density was measured at $450 \mathrm{~nm}$ using a microplate reader (Epoch, BioTek, VT, USA).

\section{Real-time PCR}

To evaluate the expression of the inflammatory markers, total RNA was isolated from HMEECs after treatment with extracellular vesicles using TRIzol reagent (Invitrogen, Carlsbad, CA, USA). RNA was reverse-transcribed using a ReverTra Ace qPCR RT Master Mix (Toyobo BioTechnology, Osaka, Japan). The following primers were 
used for sequencing: $T N F-\alpha$, forward: $5^{\prime}-$ GA GGC CAA GCC CTG GTA TG-3' and reverse: $5^{\prime}$-CG GGC CGA TTG ATC TCA GC-3'; COX-2, forward: 5'-TT GCT GGC AGG GTT GCT GGT- $3^{\prime}$ and reverse: $5^{\prime}$-TC TGC CTG CTC TGG TCA ATG G-3'; interleukin 1 $(I L-1 \beta)$, forward: 5'-TC CAG GGA CAG GAT ATG GAG-3' and reverse: 5'-CC AAG GCC ACA GGT ATT TTG-3'; interleukin 6 (IL-6), forward: 5'-AA AGA GGC ACT GGC AGA AAA- $3^{\prime}$ and reverse: $5^{\prime}$-AG CTC TGG CTT GTT CCT CAC-3'; and GAPDH, forward: 5-TC GCC CCA CTT GAT TTT GG-3 and reverse: 5-GC AAA TTC CAT GGC ACC GT-3'. The thermal cycling conditions comprised an initial denaturation at $95{ }^{\circ} \mathrm{C}$ for $15 \mathrm{~min}$, followed by 33 cycles of $94{ }^{\circ} \mathrm{C}$ for $30 \mathrm{~s}, 50{ }^{\circ} \mathrm{C}$ for $30 \mathrm{~s}$, and $72{ }^{\circ} \mathrm{C}$ for $60 \mathrm{~s}$. Real-time PCR was performed using the QuantStudio $^{\mathrm{TM}} 6$ Flex Real-Time PCR System (Applied Biosystems, Foster City, CA, USA).

\section{Confocal microscopy}

Reactive oxygen species (ROS) were detected using 1 $\mu \mathrm{M} \mathrm{2}$ 2 $^{\prime} 7^{\prime}$-dichlorodihydrofluorescein diacetate (DCFDA) in HMEECs. The cells were then incubated in a humidified $5 \% \mathrm{CO}_{2}$ incubator for $30 \mathrm{~min}$ at $37{ }^{\circ} \mathrm{C}$ after treatment with DCFDA. In contrast, CD63, an EV marker, was observed when the MSCs were incubated in 5\% normal goat serum for $1 \mathrm{~h}$ at RT to prevent non-specific labeling. Anti-CD63 (1:200, ab 118,307, Abcam, MA, USA) was used as the primary antibody for $1 \mathrm{~h}$ at $4{ }^{\circ} \mathrm{C}$. The samples were washed with PBS three times for $5 \mathrm{~min}$ each time, followed by incubation with a secondary antibody, goat anti-rabbit IgG H\&L (Alexa Fluor 488; 1:1000, ab150077, Abcam, MA, USA), for $1 \mathrm{~h}$ at RT. After washing the samples three times for $5 \mathrm{~min}$ with PBS, they were immobilized with a mounting solution containing DAPI (4,6-diamidino-2-phenylindole). All the samples were observed by confocal microscopy (Carl Zeiss Microscopy $\mathrm{GmbH}$, Jena, Germany), and the images were analyzed using ZEN lite ver. 2.3.

\section{Nanoparticle tracking analysis (NTA)}

Extracellular vesicles were quantified based on the MISEV guidelines [30]. The particle concentration, size, and distribution of the isolated MSC-derived EVs were analyzed using a NanoSight NS300 (Malvern Instruments Ltd, Malvern, UK). Typically, $1 \mathrm{~mL}$ of a 1:100 diluted MSC-derived EV was prepared for particle visualization and recording of light scattering. Three videos, each of $60 \mathrm{~s}$ recordings, were analyzed and plotted to show the EV concentration, size, and distribution.

\section{Transmission electronic microscopy (TEM)}

MSCs were fixed in $2.5 \%$ glutaraldehyde for $2 \mathrm{~h}$ at $4{ }^{\circ} \mathrm{C}$, and the samples were solidified in $2 \%$ agar. After washing with $0.1 \mathrm{M}$ cacodylate buffer, the samples were post-fixed in $1 \%$ osmium tetroxide $\left(\mathrm{OsO}_{4}\right)$. The dehydration steps were performed with $50-100 \%$ ethanol, and the samples were then embedded in Epon resin. The samples were baked overnight in an oven at $65{ }^{\circ} \mathrm{C}$, sectioned in an ultramicrotome, and examined by TEM using a field electron emission unit (JEM-1200EX-II, JEOL).

\section{Western blotting}

EVs derived from MSCs were isolated through centrifugation, and the amount of total protein was quantified using the Bradford assay. Protein samples were separated using 10\% SDS-PAGE with a mini gel apparatus (BioRad, Hercules, CA, USA) and transferred onto PVDF membranes (T831.1, Merck Millipore, MA, USA). Each membrane was blocked with $3 \%$ skim milk in Tris-buffered saline containing $0.05 \%$ Tween 20 . The primary antibodies anti-CD9 (1:1000, ab92726, Abcam, MA, USA), CD63 (1:1000, ab118307, Abcam, MA, USA), and antiCD81 (1:1000, ab109201, Abcam, MA, USA) were used as primary antibodies and were incubated overnight at $4{ }^{\circ} \mathrm{C}$. Mouse anti-rabbit IgG-HRP (sc-2357, Santa Cruz, CA, USA) was used as a secondary antibody for $1 \mathrm{~h}$. The bands were visualized using enhanced chemiluminescence according to the manufacturer's instructions (Immobilon Crescendo Western HRP substrate, Millipore, Darmstadt, Germany). The band intensities were quantified using the ChemiDoc XRS + System (Bio-Rad). All the samples were developed within $10 \mathrm{~min}$ to obtain a band.

\section{miRNA analysis}

RNA samples prepared from EVs were isolated from the single and co-culture media. The RNA from the EVs was labeled AD-M, BM-M, and T-M derived from single cultured media, such as adipose tissue (AD)-derived MSCs, bone marrow (BM)-derived MSCs, and tonsil (T)-derived MSCs. The RNA from the EVs was labeled as H:AD-M, H:BM-M, and H:T-M derived from co-culture media as AD-MSCs, BM-MSCs, and T-MSCs with HMEECs. The concentration of the sample was confirmed through quality control analysis and was confirmed to be between 0.13 and $0.28 \mathrm{ng} / \mu \mathrm{L}$. To check the purity and quantity of RNA, a NanoDrop spectrophotometer was used to measure the absorbance at 260 and $280 \mathrm{~nm}$. All raw data were extracted automatically using the Affymetrix data extraction protocol using the Affymetrix GeneChip ${ }^{\circledR}$ Command Console ${ }^{\circledR}$ Software (AGCC). The CEL files were imported, miRNA levels were normalized using the RMA algorithm, the detection above background p-values was calculated for all data, and the results were exported using the Affymetrix ${ }^{\circledR}$ Power Tools (APT) software. Array data were filtered using species-specific annotated 
probes. Comparative analysis between the test and control samples was performed using fold change. All statistical testing and visualization of differentially expressed genes were conducted using the $\mathrm{R}$ statistical language 3.3.3 (https://www.r-project.org/). All the predicted mRNAs from the miRNAs in the EVs were analyzed using the NCBI database, ExoCarta (http://www.exoca rta.org/), and Vesiclepedia (http://microvesicles.org/).

\section{Statistical analysis}

Statistical analysis was performed using the SPSS statistical package (version 21.0; SPSS Inc., USA). All graphs were plotted using GraphPad PRISM (version 5.0; GraphPad Inc., La Jolla, CA, USA). The descriptive results of continuous variables are expressed as mean \pm standard deviation (SD) for normally distributed variables. The means were compared using a two-way analysis of variance. The level of statistical significance was set at $\mathrm{p}<0.05$.

\section{Results}

Validation of mesenchymal stem cells derived from adipose tissue, bone marrow, and tonsil using FACS

To confirm the effects of MSCs in various locations in the human body, we obtained MSCs from three different human tissues. Adipose tissue-, bone marrow-, and tonsil-derived MSCs have been reported to have cell proliferation and inflammation alleviation efficacy in various studies [4]. We established conditions for purely separating primary cultured MSCs from fresh tissues, and all the samples were validated with specific markers using FACS (Fig. 1a). All the tissues were collected from human donors at our institute. As shown in Fig. 1b, the expression of CD markers in MSCs was demonstrated as CD90, CD105, and CD73, and CD44 in FACS. The MSCs derived from adipose tissue, bone marrow, and tonsils showed similar morphology using microscopy (Fig. 1c). They were labeled AD-MSC, BM-MSC, and T-MSC since they are MSCs derived from the adipose tissue, bone marrow, and tonsil, respectively (a) The process of extracting and validating MSCs from three tissues, (b) The validation result of MSCs by FACS. MSCs were positive for CD90, CD105, and CD73 and negative for CD44, (c) Microscopic image of AD-MSC, BM-MSC, and $\mathrm{T}$-MSC $(\mathrm{bar}=10 \mu \mathrm{m})$.

Increased levels of inflammatory markers by LPS on human middle ear epithelial cells

Anti-inflammation research using MSCs has been reported in various fields [4]. In this study, we aimed to compare the anti-inflammatory effect of MSCs derived from three different tissues; therefore, we decided

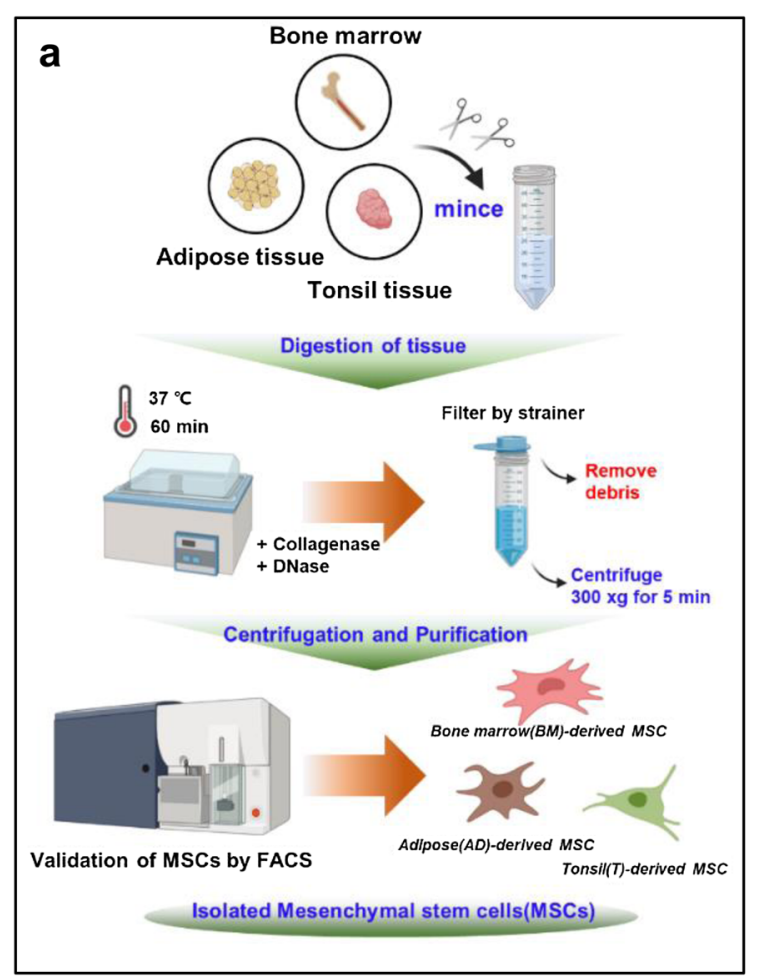

b
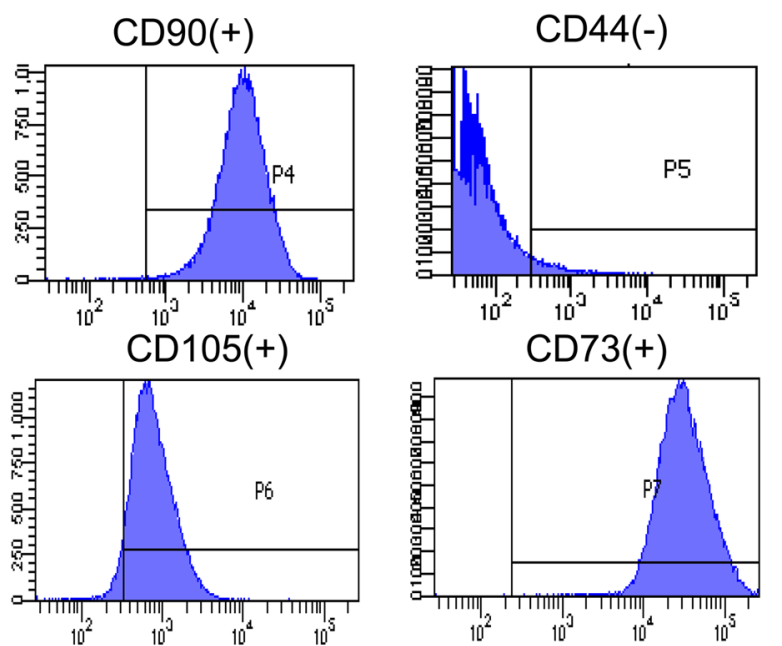

C

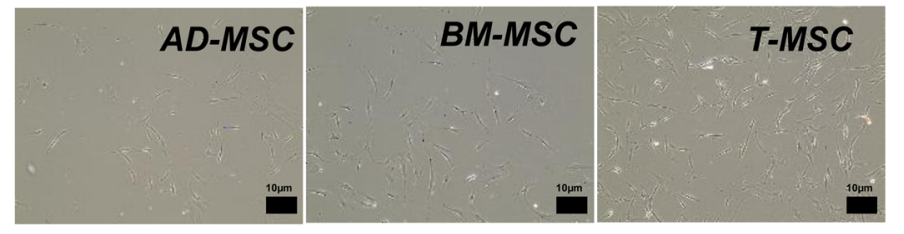

Fig. 1 Extracted and validated MSCs from the adipose tissue, bone marrow, and tonsil tissue in humans 
to use an in vitro model that can be used for a clinical study related to inflammation. HMEECs are used in OM research because they are easy to access as an initial model to prove the effect between anti-inflammatory reactions with stem cells [26]. We selected the effective concentration (FC20) that showed $81 \%$ from $1 \mu \mathrm{g} / \mathrm{mL}$ viability after $24 \mathrm{~h}$ (Fig. 2a) and $83 \%$ after $24 \mathrm{~h}$ with $1 \mu \mathrm{g} /$ mL LPS (Fig. 2b) because HMEECs must be maintained to extract cell-derived RNA to measure inflammatory factors. Cell imaging via microscopy showed that dead cells were observed by LPS (Fig. 2c and d). To confirm the expression of inflammatory markers, we designed four primers $(C O X-2, T N F-\alpha, I L-1 \beta$, and $I L-6)$ for realtime PCR and found that the expression levels of these markers were increased by $1 \mu \mathrm{g} / \mathrm{mL}$ LPS for $24 \mathrm{~h}$. The expression level increased rapidly after $6 \mathrm{~h}$ and remained constant after $24 \mathrm{~h}$ (Fig. 2e-h).

Evaluated cell viability and ROS reduction in the co-culture condition between HMEEC and MSC derived from adipose tissue, bone marrow, and tonsils

Since it is difficult to directly confirm the anti-inflammatory effect of donor cells using MSCs, we tried to prove the anti-inflammatory effect using EVs generated from the co-culture medium. EVs have been reported to occur even in MSC single cultures [32], but the effect of EVs in the co-culture media has not been reported. We hypothesized that since EVs play a role in cell-cell communication, internal substances (miRNAs, proteins, cytokine etc.) change because of the crosstalk between cells [21, 33]. Therefore, adipose-derived MSCs (AD-MSCs), bone marrow-derived MSCs (BM-MSCs), and tonsil-derived MSCs (T-MSCs) were cultured alone. The EVs in the single culture media were labeled as AD-M, BM-M, and T-M. In addition, AD-, BM-, and T-MSCs were cocultured with HMEECs in a transwell plate to obtain a co-culture medium. The EVs in the co-culture media between MSCs and HMEECs were labeled H:AD-M, H:BM-M, and H:T-M (Fig. 3a). All the EVs were purified using an exosome isolation kit with high centrifugation and were validated in various ways. The efficacy of the EVs was compared after inducing inflammation with LPS in HMEECs pre-treated with EVs (Fig. 3b).

Cell viability was evaluated, as shown in Fig. 3c. When HMEECs were co-cultured with AD-MSCs, BM-MSCs, and T-MSCs, the cell viability was maintained at over $98 \%$ for 3 and $24 \mathrm{~h}$. In other words, it was found that HMEECs and MSCs do not cause toxicity to each other through crosstalk. Interestingly, it was also observed that the ROS levels were reduced by the three MSCs after ROS production was stimulated by LPS in HMEECs (Fig. 3d). This suggests that they can be reduced by
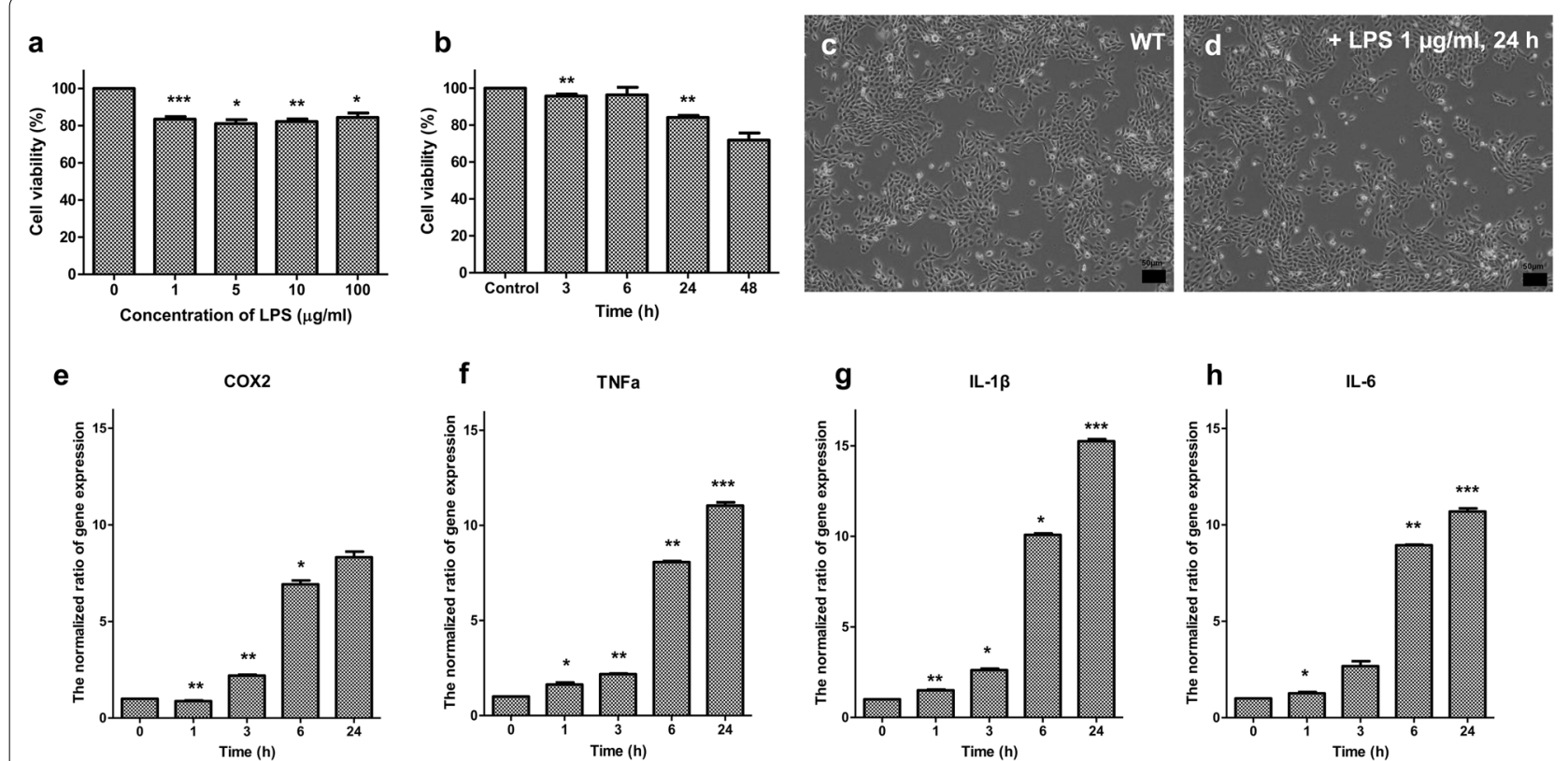

Fig. 2 Cell viability and expression of TNF- $a, C O X-2, I L-1 \beta$, and IL-6 in HMEECs upon LPS treatment. a The viability of HMEECs after treatment with $1,5,10$, and $100 \mu \mathrm{g} / \mathrm{mL}$ LPS for $24 \mathrm{~h}$, b The viability of HMEECs treated with $1 \mu \mathrm{g} / \mathrm{mL}$ LPS for 1, 3, 6, 24, and $48 \mathrm{~h}$, c Image of wild-type HMEECs; d Image of HMEECs after treatment with $1 \mu \mathrm{g} / \mathrm{mL}$ LPS for $24 \mathrm{~h}$, e COX-2 expression level in HMEECs after treatment with $1 \mu \mathrm{g} / \mathrm{mL}$ LPS for $24 \mathrm{~h}$, f TNF- $a$ expression level in HMEECs after treatment with $1 \mu \mathrm{g} / \mathrm{mL}$ LPS for $24 \mathrm{~h}, \mathbf{g} / \mathrm{L}-1 \beta$ expression level in HMEECs after treatment with $1 \mu \mathrm{g} / \mathrm{mL} \mathrm{LPS}$ for $24 \mathrm{~h}$, h $/ L-6$ expression level in HMEECs after treatment with $1 \mu \mathrm{g} / \mathrm{mL}$ LPS for $24 \mathrm{~h}$ ( $\mathrm{p}$-value: ${ }^{* *}<0.001,{ }^{* *}<0.01,{ }^{*}<0.05$ ) 


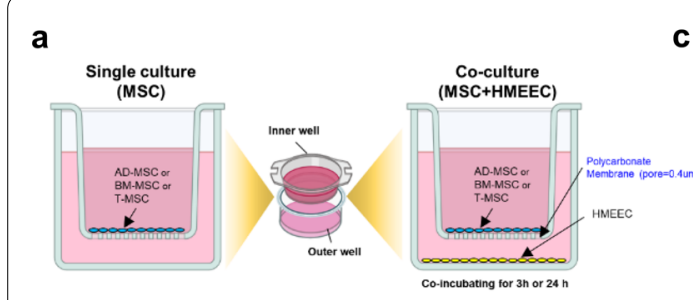

b

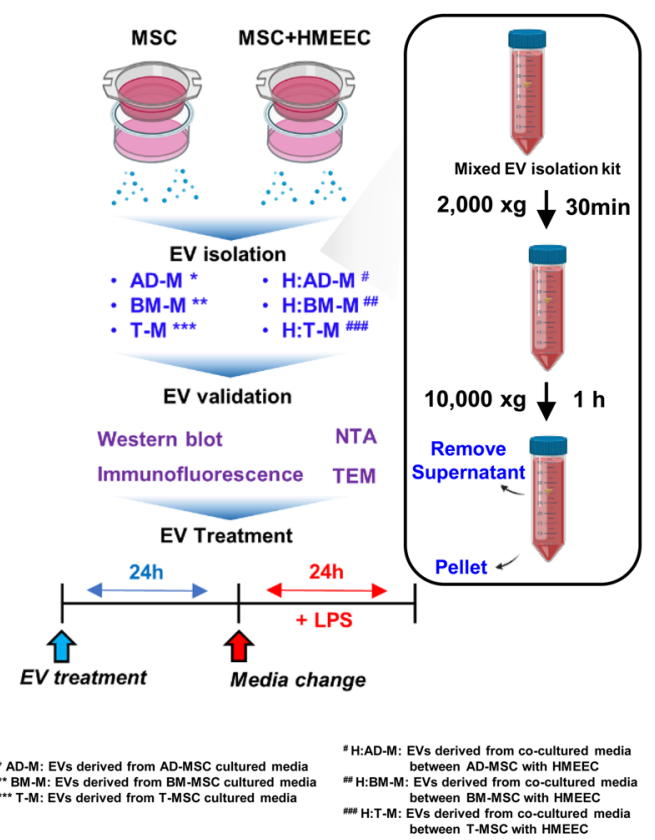

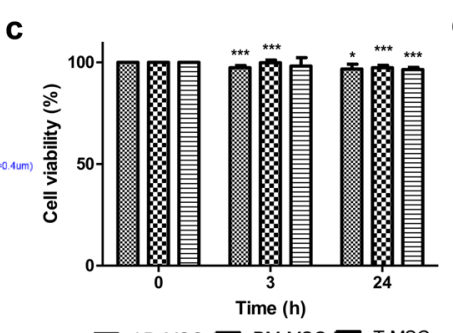

AD-MSC $\propto 3$ BM-MSC 曰

e

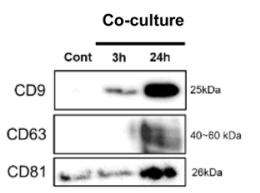

g

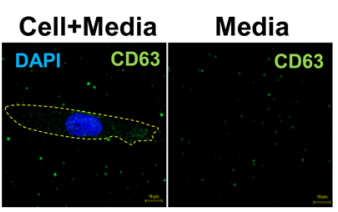

h

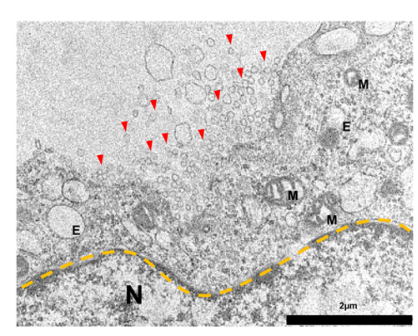

d

f

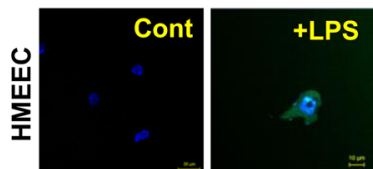

Co-culture for $24 \mathrm{~h}$
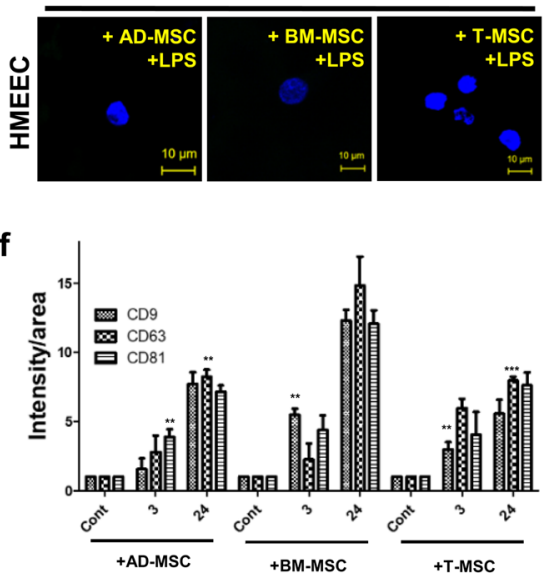

i

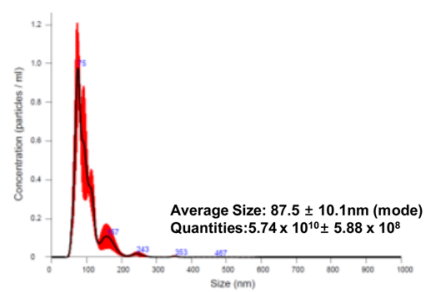

Fig. 3 Schematic diagram of co-culture conditions and extraction and evaluation of MSC-derived EVs. a Scheme of culture condition, $\mathbf{b}$ Flow chart for EV isolation and treatment of HMEECs, c The viability of HMEECs when co-cultured with AD-MSC, BM-MSC, and T-MSC for 3 and $24 \mathrm{~h}$ ( $p$-value: ${ }^{* *}<0.001,{ }^{* *}<0.005,{ }^{*}<0.05$ ), $\mathbf{d}$ Evaluation of ROS reduction in HMEECs treated with LPS after co-culture with AD-MSC, BM-MSC, and T-MSC for $24 \mathrm{~h}$, e The expression of CD9, CD63, and CD81 protein bands in the co-culture media, $\mathbf{f}$ The normalized intensity of CD9, CD63, and CD81 with the area in the co-culture media ( $p$-value: ${ }^{* * *}<0.001,{ }^{* *}<0.005,{ }^{*}<0.05$ ), $\mathbf{g}$ The expression of CD63 as an EV marker in the MSC culture media (yellow circle represents the cellular membrane), $\mathbf{h}$ The image of EVs (red arrow) released from the MSC, $\mathbf{i}$ The size and concentration analysis in EVs by NTA

substances generated during co-culture with MSCs; therefore, it was hypothesized that the ROS-reducing substances in the co-culture medium were EVs. In addition, the amount of protein was evaluated in EVs through specific EV markers, such as CD9, CD63, and CD81 in co-culture media, and it was observed that the protein expression level gradually increased at 3 and $24 \mathrm{~h}$ (Fig. 3e). When co-cultured with AD-MSCs, BM-MSCs, and T-MSCs, the ratio of the amount of protein showed a similar tendency even when the amount of protein was quantified by area (Fig. 3f). The fluorescence images of EVs were analyzed in MSC culture media using the EV marker CD63 through immunofluorescence (IF) (Fig. 3g). Green fluorescence intensity was detected in the media, except cells, and the phenome of EVs released from the
MSC surface was observed through TEM (Fig. 3h). In addition, the EVs dissolved in the media were measured by NTA; the EV size was $87.5 \pm 10.1 \mathrm{~nm}$, and the concentration of EV was $5.74 \times 10^{10} \pm 5.88 \times 10^{8}$ particles $/ \mathrm{mL}$ (Fig. 3i). Therefore, we observed that the three MSCs and HMEECs could be co-cultured without toxicity by crosstalk and it can be predicted that a substance that reduces ROS is contained in the EV.

Decreased TNF- $\alpha$, COX-2, IL-1 $\beta$, and IL- 6 in co-culture media ROS levels were reduced by co-culture with the three MSCs, but we isolated EVs from the media. When the HMEECs were co-cultured with the three MSCs and exposed to LPS, LPS stimulated both the MSCs and HMEECs. To evaluate the efficacy of the purified EVs, 
they should be isolated from the media and compared with single culture media. The viability of HMEECs was evaluated using EVs isolated from single culture media (AD-M, BM-M, and T-M) and EVs extracted from coculture media (H:AD-M, H:BM-M, and H:T-M). When LPS was treated at $1 \mathrm{mg} / \mathrm{mL}$ for $24 \mathrm{~h}$ as EC20, the cell viability was approximately $81 \%$. In contrast, the viability of HMEECs treated with AD-M, BM-M, and T-M for 6-48 h was $98 \%$ (Fig. 4a). It also showed that the viability of HMEECs was more than $97 \%$ when treated with H:AD-M, H:BM-M, and H:T-M for 6-48 h (Fig. 4b). Since the stability of the extracted EVs was confirmed, we compared the effect of inflammatory factors in HMEECs that induced inflammation by EC20 concentration of LPS.

To evaluate the anti-inflammatory effect of EVs isolated from single and co-culture media, the RNA expression level was confirmed through real-time PCR. To confirm the anti-inflammatory effect of EVs extracted from a single culture medium and co-culture medium, the expression of RNA inflammatory factor generation was observed using real-time PCR. After treating with EVs, the HMEEC cultured media was changed and treated with LPS for $0.5,1,3,6,24$, and $48 \mathrm{~h}$. EVs derived from single culture media, AD-M, BM-M, T-M, showed decreased levels of TNF- $\alpha$ after $1 \mathrm{~h}$ of exposure, which were $7.0 \pm 0.64$ to $4.41 \pm 0.17$ by $\mathrm{AD}-\mathrm{M}, 3.41 \pm 0.13$ by BM-M, and $3.34 \pm 0.31$ by T-M (Fig. 4c). In contrast, EVs derived from the co-culture medium $\mathrm{H}: \mathrm{AD}-\mathrm{M}, \mathrm{H}: \mathrm{BM}-\mathrm{M}$, and H:TM showed decreased levels of TNF- $\alpha$ after $1 \mathrm{~h}$ of exposure, which were $2.53 \pm 0.12$ by H:AD-M, $0.29 \pm 0.04$ by H: BM-M, and $2.44 \pm 0.04$ by H:T-M (Fig. 4c). Interestingly, in the case of EVs derived from co-culture media, the TNF- $\alpha$ expression level did not increase within $1 \mathrm{~h}$ by H:BM-M (Fig. 4c). H:AD-M and H:T-M showed similar expression levels to $\mathrm{AD}-\mathrm{M}$ and $\mathrm{T}-\mathrm{M}$. The expression level of COX-2 stimulated by LPS confirmed that BM-M and $\mathrm{T}-\mathrm{M}$ showed decreased expression levels after $24 \mathrm{~h}$ rather than AD-M.

It was also confirmed that the expression of COX-2 was reduced by co-culture medium-derived EVs. EVs derived from single culture media, $\mathrm{AD}-\mathrm{M}, \mathrm{BM}-\mathrm{M}$, and $\mathrm{T}-\mathrm{M}$, showed that the expression level of COX-2 decreased after $3 \mathrm{~h}$ of exposure, which were $5.59 \pm 0.16,1.71 \pm 0.03$, $2.83 \pm 002$, and $1.95 \pm 0.01$, respectively. In contrast, EVs derived from the co-culture medium $\mathrm{H}: \mathrm{AD}-\mathrm{M}, \mathrm{H}: \mathrm{BM}-\mathrm{M}$, and H:TM decreased the expression level of COX-2 after $3 \mathrm{~h}$. $\mathrm{t}$ was confirmed that the expression level of COX-2 also decreased significantly which showed $1.64 \pm 0.08$ by $\mathrm{H}: \mathrm{AD}-\mathrm{M}, 0.08 \pm 0.34$ by $\mathrm{H}: \mathrm{BM}-\mathrm{M}$, and $1.66 \pm 0.01$ by H:T-M after $1 \mathrm{~h}$ (Fig. 4d). In addition, it was confirmed that the IL-1 $\beta$ expression level decreased after $3 \mathrm{~h}$ by BM-M and T-M, but not by AD-M. EVs derived from single culture media, $\mathrm{AD}-\mathrm{M}, \mathrm{BM}-\mathrm{M}$, and $\mathrm{T}-\mathrm{M}$, showed that the expression level of IL-1 $\beta$ decreased after $3 \mathrm{~h}$ exposure, which were $7.55 \pm 0.73$ to $3.18 \pm 0.02$ by AD-M, $4.08 \pm 0.04$ by BM-M, and $3.64 \pm 0.01$ by T-M (Fig. 4e). In contrast, EVs derived from the co-culture media H:AD-M, H:BM-M, and H:TM decreased the expression level of IL-1 $\beta$ after $3 \mathrm{~h}$, which were $2.89 \pm 0.75$ by $\mathrm{H}: \mathrm{AD}-\mathrm{M}, 0.35 \pm 0.611$ by $\mathrm{H}$ : BM-M, and $3.44 \pm 0.13$ by H:T-M. As a result, by EVs derived from the co-culture medium, IL-1 $\beta$ decreased after $1 \mathrm{~h}$, and in particular, $\mathrm{H}: \mathrm{BM}-\mathrm{M}$ significantly reduced the expression of IL-1b after $3 \mathrm{~h}$ (Fig. 4e). The expression level of IL-6 was also reduced by EVs derived from MSC culture media after stimulation by LPS. EVs derived from single culture media, AD-M, BM-M, and T-M, showed that the expression level of IL- 6 decreased after $3 \mathrm{~h}$ exposure, which were $3.43 \pm 0.18$ to $1.7 \pm 0.04$ by $\mathrm{AD}-\mathrm{M}, 2.88 \pm 0.04$ by $\mathrm{BM}-\mathrm{M}$, and $2.13 \pm 0.02$ by T-M (Fig. 4f). In contrast, EVs derived from the co-culture media H:AD-M, H:BM-M, and H:TM decreased the expression level of IL- 6 after $3 \mathrm{~h}$, which were $1.33 \pm 0.42$ by H:AD-M, $0.049 \pm 0.15$ by $\mathrm{H}$ : BM-M, and $1.33 \pm 0.64$ by H:T-M. Almost all expression levels decreased in the positive control, the AD-M, $B M-M$, and T-M groups showed no decrease in gene expression levels after $48 \mathrm{~h}$. However, IL-6 was significantly decreased after $30 \mathrm{~min}$ by $\mathrm{H}: \mathrm{BM}-\mathrm{M}$, and the expression level decreased after $3 \mathrm{~h}$ (Fig. 4f).

\section{Increased miRNA expression level in EVs by co-culture condition}

The inflammatory factors were confirmed to significantly decrease in a short time in H:BM-M; therefore, we hypothesized that it would have been reduced by the factor possessed by EVs. In particular, in H:BM-M, it was hypothesized that the payload of a specific factor increases, and some studies have reported that some of the miRNA levels may vary depending on the co-culture conditions $[9,33,34]$.

As a result of miRNA analysis by EVs derived from cultured media in six different environments, we confirmed that a total of 161 miRNA expression levels changed (Fig. 5a). Interestingly, as shown in the heatmap, it was confirmed that the miRNA level increased significantly under co-culture conditions. The miRNA expression level was compared by a fold change value of 1.5 and 2 times (Fig. 5b). At 1.5 times, the expression of miRNA in AD-M and $\mathrm{H}: \mathrm{AD}-\mathrm{M}$ showed an increase of 85 miRNAs and a decrease of 46 miRNAs. The expression level of miRNA in BM-M and $\mathrm{H}: \mathrm{BM}-\mathrm{M}$ showed an increase of 125 miRNAs and a decrease of 5 miRNAs. The expression levels of miRNAs in T-M and H:T-M showed an increase of 126 miRNAs and a decrease of 1 miRNA. In addition, the expression level 


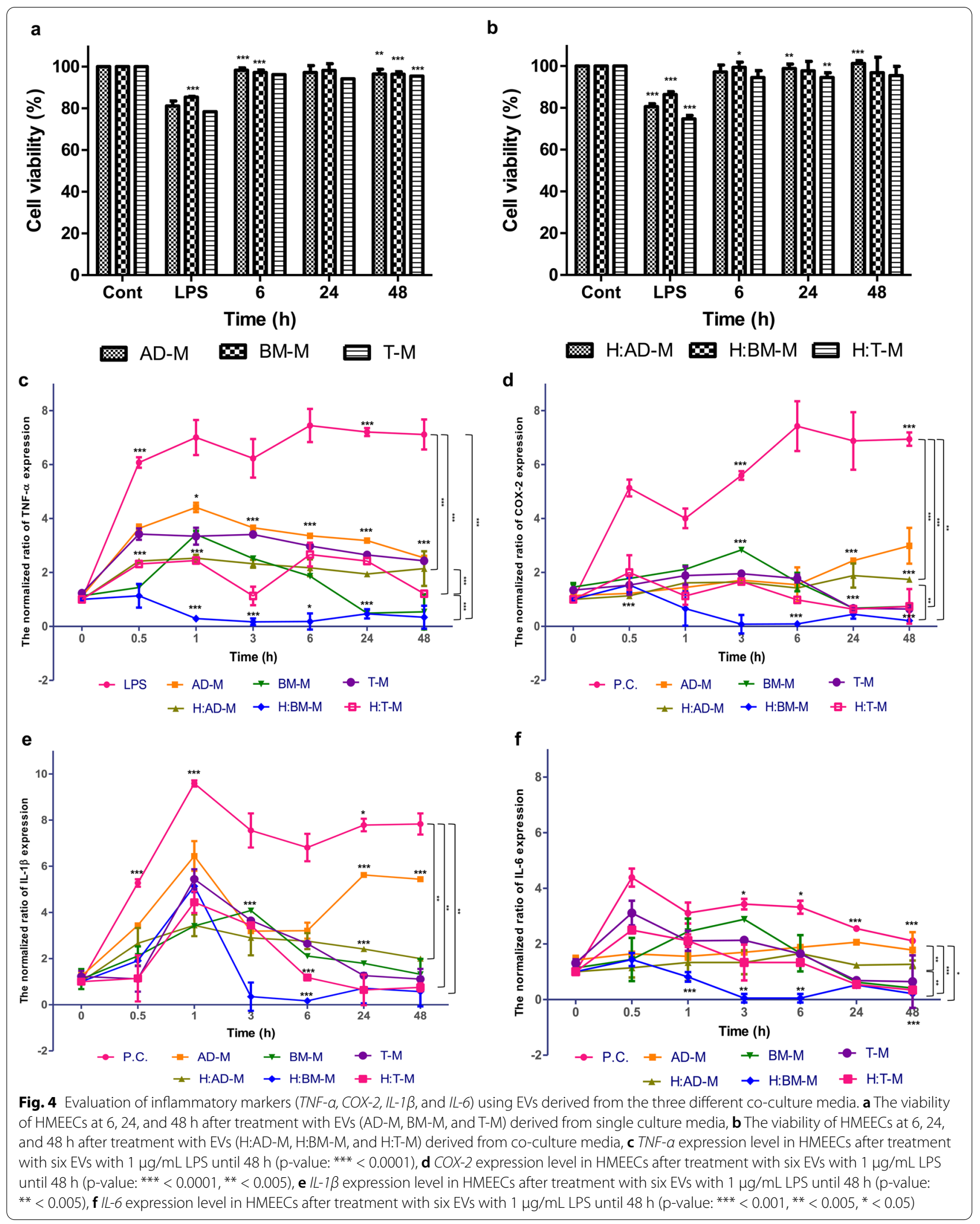


a
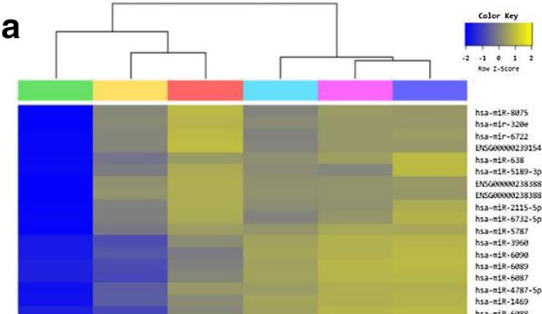

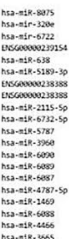
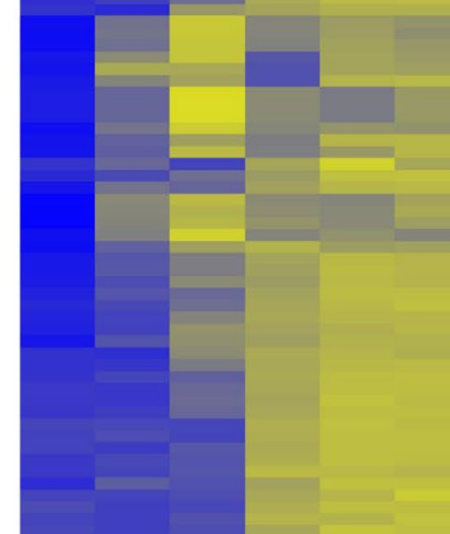

b

Up, Down regulated probes count
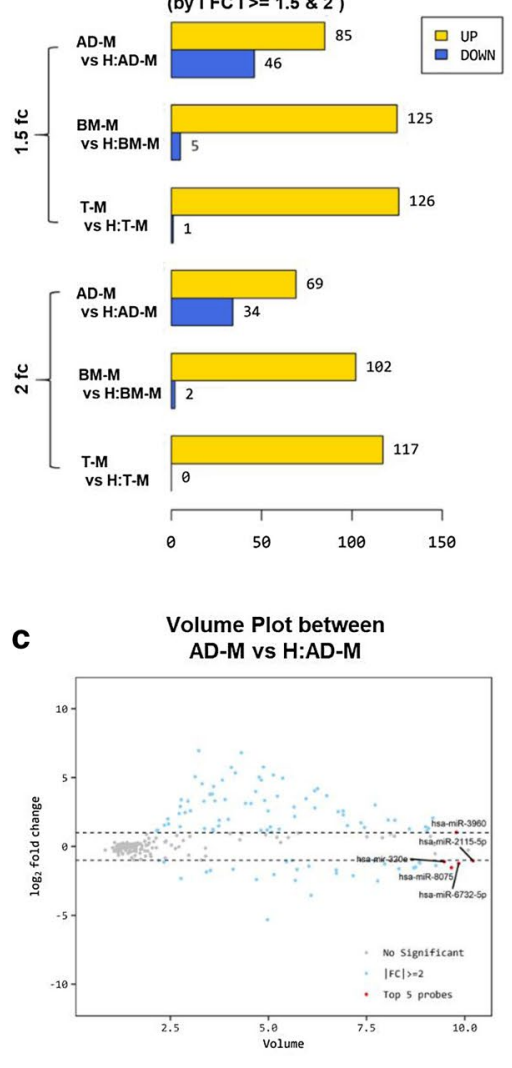

d

Volume Plot between

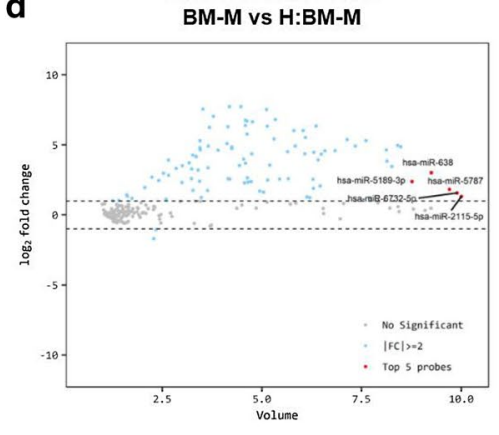

Volume Plot between T-M vs H:T-M

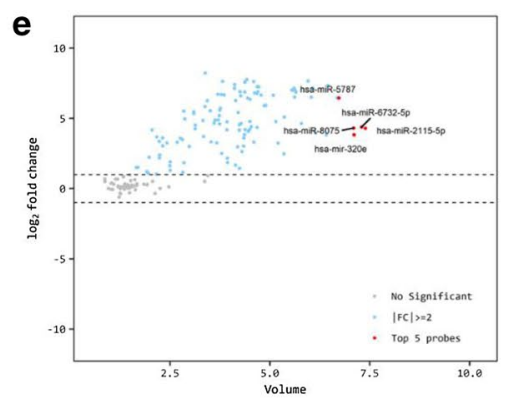

Fig. 5 The data of miRNA analysis. a The heatmap of miRNA expression in EVs (AD-M, BM-M, T-M, H:AD-M, H:BM-M, and H:T-M), b The comparison of probe count in up- and downregulation between the six EVs, cThe volume plot between AD-M and H:AD-M, d The volume plot between BM-M and $\mathrm{H}: \mathrm{BM}-\mathrm{M}$, e The volume plot between T-M and H:T-M 
of miRNA was analyzed as a 2-fold change. There were 69 miRNAs and 34 downregulated miRNAs in the AD-M and H:AD-M groups. There were 102 miRNAs and two decreased miRNAs in BM-M and H:BM-M. There were 117 upregulated miRNAs in the T-M and $\mathrm{H}: \mathrm{T}-\mathrm{M}$ groups.

Furthermore, to analyze the miRNAs increased by co-culture, we selected the top five miRNAs with a large increase in expression level. Comparing IAD-M and $\mathrm{H}: \mathrm{AD}-\mathrm{M}$, the highest miRNA expression was hsa-miR-3960, hsa-miR-2115-5p, hsa-miR-320e, hsamiR-8075, and hsa-miR-6732-5p (Fig. 5c). In addition, in the results of comparing BM-M and $\mathrm{H}: \mathrm{BM}-\mathrm{M}$, the highest miRNA expression was hsa-miR-638, hsamiR-5787, hsa-miR-5189-3p, hsa-miR-6732-5p, and hsa-miR-2115- It is 5p (Fig. 5d). Finally, the results of comparing T-M and $\mathrm{H}: \mathrm{T}-\mathrm{M}$, the highest miRNA expression were hsa-miR-2115-5p, hsa-miR-5787, hsa-miR-6732-5p, hsa-miR-8075, and hsa-miR-320e (Fig. 5e). Interestingly, miRNAs that overlapped with each other were found, and a large amount of miRNA was observed to increase in $\mathrm{H}: \mathrm{BM}-\mathrm{M}$.

To confirm the intersection of each EV sample from the three different MSCs, we performed a band diagram analysis and found that a total of 51 miRNAs were changed for overlapping factors under the three conditions (Fig. 6a). In addition, the number of upregulated miRNAs was 42 under the three conditions (Fig. 6b), and the decreased miRNA did not intersect in the TM vs. H:TM samples and one was found in $A D-M$ vs. H:AD-M and BM-M vs. H:BM-M (Fig. 6c).
The amyloid-based binding proteins combined to decrease inflammatory factors in $\mathrm{H}: \mathrm{BM}-\mathrm{M}$

Following the results of miRNA analysis, we analyzed gene ontology $(\mathrm{GO})$ to understand the role and biological function of proteins related to these miRNAs. In a previous experiment, we confirmed that when EVs were pre-treated with HMEEC and then induced inflammation with LPS, the result of rapidly reducing the inflammatory factor after $1 \mathrm{~h}$ by EVs derived from co-culture media (Fig. 4). It was assumed that there would be information on useful molecules in $\mathrm{H}: \mathrm{BM}-\mathrm{M}$, which significantly reduced the gene expression of TNF- $\alpha$, COX-2, IL-1 $\beta$, and IL- 6 in inflammation-induced cells. Therefore, we analyzed the expression of miR-638, which was highly expressed in $\mathrm{H}$ :BM-M.

First, most of the proteins expressed for miR-638 included factors that affected the development of intracellular proteins in donor cells. It is also involved in RNA transcription polymerase-related factors and cell-cell signaling. In addition, there was a small expression level related to the factors involved in differentiation (Fig. 7a).

Next, the relevance of the cellular component was analyzed, and an association with a total of 10 organelles was shown. The predicted proteins were mainly related to the intracellular, membrane, and cytoplasm (Fig. 7b). In addition, among them as a result of analyzing molecular function, it was confirmed that the factors related to protein binding significantly increased. In particular, the expression of the amyloid-beta binding protein was found to be the largest (Fig. 7c). It has been reported that amyloid-beta A4 precursor protein-binding family A member 2 (APBA2) is involved in synaptic transport and junction of neurons [35], but they are also

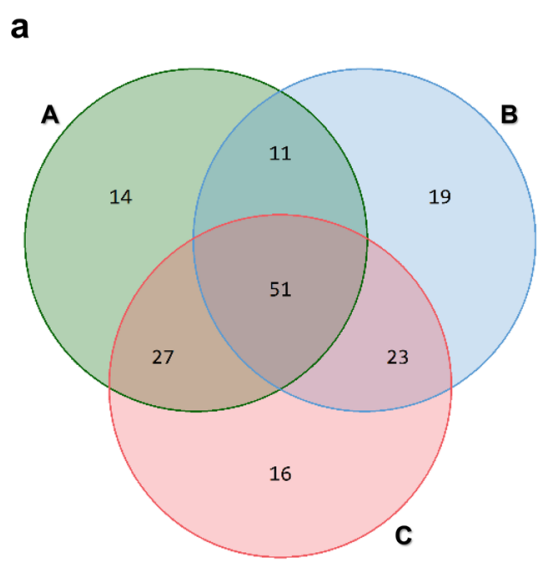

All sample regulation b

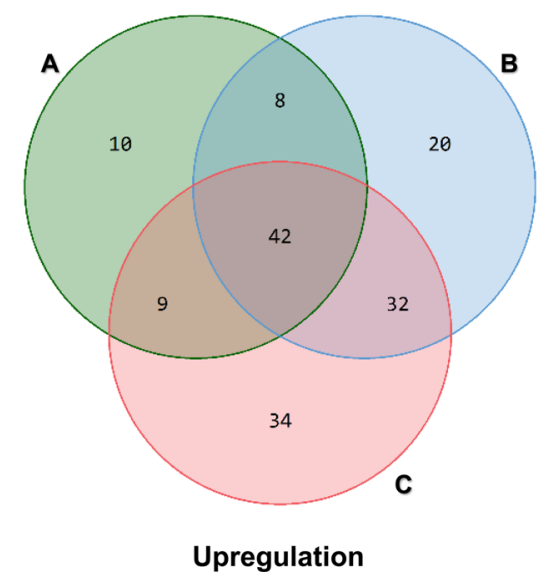

C

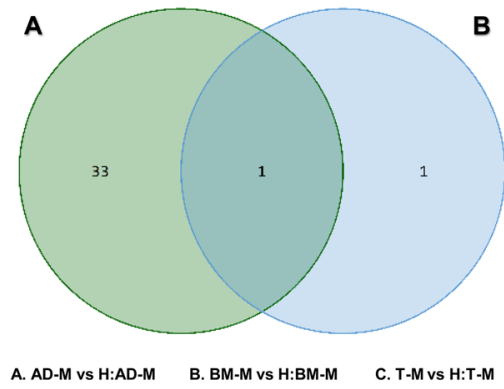

Downregulation

Fig. 6 Venn diagram of logical miRNA relations in EVs (A, AD-M and H:AD-M; B, BM-M and H:BM-M; C, T-M and H:T-M). a Total regulation of all miRNA regulation for three groups, $\mathbf{b}$ Upregulation, $\mathbf{c}$ downregulation 


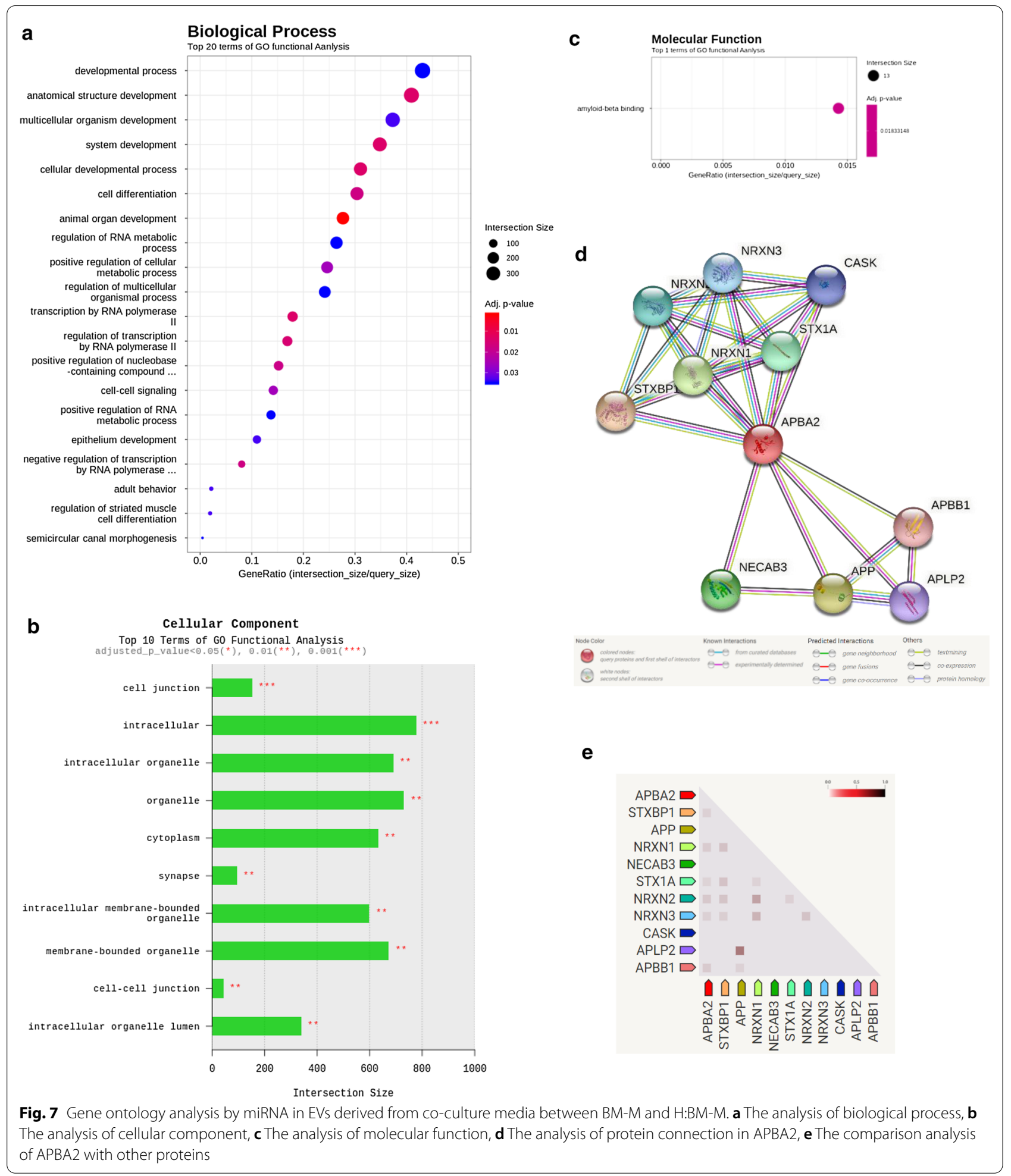

involved in improving immunity and cell regeneration [36]. We hypothesized that the anti-inflammatory effect of HMEECs was increased by the expression of miRNA638 in $\mathrm{H}: \mathrm{BM}-\mathrm{M}$ and APBA2 could be expected to be a candidate connection protein (Fig. 7d). APBA2 also showed an association of 0.989 with STXBP1 and a low association with NRXN1 and STX1A (Fig. 7e). Therefore, we concluded that BM-MSCs significantly increased 
the expression of APBA2-related proteins in EVs in the medium by exchanging substances with HMEEC, thereby improving the anti-inflammatory effect of HMEECs.

\section{Discussion}

Research on the development of therapeutic materials using human MSC-derived EVs has been actively reported in the field of regenerative medicine and antiinflammatory materials [5,37, 38]. Representative human stem cells of various origins, such as adipose tissue, bone marrow, umbilical cord, and tonsil, have been reported $[5,14]$. Interestingly, some studies have reported that MSCs derived from different tissues have different payloads to communicate with recipient cells as donor cells by using EVs with a determined size of less than $100 \mathrm{~nm}$ $[5,14]$. However, there has not been a study comparing the components of MSC-derived EVs of different origins to discover therapeutic materials for inflammatory diseases or cancer diseases.

We hypothesized that EVs derived from different origin influence different inflammatory effects on one recipient cell. Here, we would like to propose that two new facts. (1) The anti-inflammatory effects of EVs derived from MSCs of different origins are indicated by differences in payloads. (2) Crosstalk between cells by co-culture can improve anti-inflammatory effects by altering the payload of EVs. MSCs were extracted from three different origin (Adipose tissue, Bone marrow, and Tonsil), and the change in payload of EVs obtained by co-culture with middle ear epithelial cells (HMEEC) in transwells was analyzed. Adipose tissue (AD)-derived MSCs express mRNAs related to transcription factors, angiogenesis, and adipogenesis $[18,27]$. Bone marrow (BM)-derived MSCs are widely known for their regenerative, immune stimulatory, and related factors, such as calcium signaling and cytoskeletal genes [20]. Tonsil (T)-derived MSCs have been reported as cells whose clinical therapeutic efficacy has been confirmed through studies in which the expression of inflammatory cytokines was increased through injection in acute and chronic colitis models $[28,39]$. In this study, using a model that causes otitis media $(\mathrm{OM})$, a disease with a high incidence in children, we confirmed the efficacy of MSC-derived EV to reduce inflammatory factors (TNF- $\alpha, \mathrm{COX}-2, \mathrm{IL}-1 \beta$, and IL-6). The expression of inflammatory factors, induces immune regulation, mucosal changes, and inflammatory responses, leading to the development of OM [26]. Among these, $T N F-\alpha$, which plays an important role in the induction of an inflammatory cascade, is known to induce OM [39]. COX-2 is the major enzyme that converts arachidonic acid to prostaglandin $\mathrm{H} 2$ to produce inflammatory mediators. The expression level of $\mathrm{COX}-2$ was upregulated in the middle ear of patients with $\mathrm{OM}$ compared to that in healthy subjects [40]. It has been reported that it can damage hearing if the inflammation of HMEECs increases significantly [41]. OM is mainly focused on in clinical research, but this finding of molecules in stem cell-derived EVs can be valuable in development of a new material by reducing the death of middle ear cells and ROS reduction by inflammatory factors [41].

The viability of HMEECs was over $98 \%$ during co-culture with AD-MSCs, BM-MSCs, and T-MSCs, as verified by FACS (Fig. 1b), confirming that no toxic substances were generated. The expression levels of inflammatory markers significantly increased after $24 \mathrm{~h}$ of exposure to $1 \mu \mathrm{g} / \mathrm{mL}$ LPS, and the cell viability also decreased to less than $80 \%$. We found that apoptosis was induced by exposure to LPS after $24 \mathrm{~h}$ (Fig. 2).

To analyze the change in payload in the MSC-derived EVs that we hypothesized, donor MSCs and recipient HMEECs were co-cultured in trans wells. The EVs were separated from the co-culture medium by centrifugation, and it was confirmed that ROS production induced by LPS was decreased by EVs in HMEECs (Fig. 3d). Based on these results, it was proved that the MSC-derived EVs, which are labeled AD-M, BM-M, and T-M in a single culture, contained factors capable of reducing ROS levels. Furthermore, there might be several useful factors expressed in co-culture media because large amounts of CD9, CD63, and CD81 (EV markers) were found after co-culture of $24 \mathrm{~h}$ (Fig. 3e and f). In other words, the co-culture conditions showed that EV generation can be increased by the crosstalk between donor and recipient cells, suggesting that the payload can be changed.

It was confirmed that the size of EVs in the single medium and co-culture media was less than 100 $\mathrm{nm}$ (Fig. $3 \mathrm{~h}$ and i), and the levels of inflammatory factors expressed by LPS were decreased by EVs. The EVs derived from MSC single culture media (AD-M, BM-M, and T-M) reduced the mRNA expression levels of TNF$\alpha, C O X-2, I L-1 \beta$, and $I L 6$ by half (Fig. 4). Interestingly, among the EVs derived from co-culture media (H:AD-M, $\mathrm{H}: \mathrm{BM}-\mathrm{M}$, and H:T-M), H:BM-M showed the greatest efficiency in reducing inflammatory factor expression until zero by pretreatment with HMEECs for $3 \mathrm{~h}$. Therefore, we hypothesized that some molecules had been delivered to the recipient cells, which is related to reduced expression of inflammatory factors.

The useful factors contained in EVs and some miRNA databases were analyzed by miRNA analysis (Fig. 5). Using miRNA analysis, we found that 161 miRNAs were expressed under the three co-culture conditions, and these were related to the effects of immunity and proliferation on the cells (described in Table 1). miR-3960 was highly expressed in H:ADM, H:BM-M, and H:T-M. The predicted mRNA levels 
Table 1 List of predicted target mRNAs by analysis of miRNAs in EVs derived from the co-culture media (AD-H:AD, BM-H:BM, TM-H:TM)

miRNA Predicted target mRNA

Symbol
Function and detail
Reference

ExoCerta, Vesiclepidia PMID

(a) Predicted target genes on the increased expression of miRNA under three conditions (AD-H:AD, BM-H:BM, TM-H:TM)

$\operatorname{miR}-3960$

POU3F3

POU class 3 homeobox 3

Regulation of oncogenic signaling

VP_5455

[42]

pathway

Interaction with SMAD protein and the tumor suppressor PTEN

Pcdha2 Protocadherin alpha 2

Establishment and function of specific

ExoCarta 393086

miR-5787 PACS1

PPP1R7

VSX2

Visual system homeobox 2

SMAD2, SMAD3 SMAD family member 2, SMAD family member 3

SYT1 Synaptotagmin I cell-cell connections.

Demonstrate an organization similar to that of B-cell and T-cell receptor gene

CERS1 Ceramide synthase 1

Encodes a ceramide synthase enzyme, which catalyzes the synthesis of ceramide

Encodes growth differentiation factor from a monocistronic mRNA

EGR Early growth response

May also play a role in a wide variety of processes including muscle development, lymphocyte development, endothelial cell growth and migration, and neuronal development

MIF

Macrophage migration inhibitory factor

Encodes a lymphokine involved in immunoregulation, cell-mediated immunity, and inflammation

(b) Predicted target genes on the increased expression of miRNA under two conditions (BM-H:BM, TM-H:TM)
Plays a role in Nef-mediated downregulation of cell surface MHC-I molecules to the TGN, thereby enabling harmful factors to escape immune surveillance

Encodes a protein subunit that regulates the activity of the serine/ threonine phosphatase, protein phosphatase-1

Encodes a homeobox protein originally described as a retina-specific transcription factor

Functions in the transforming growth factor-beta signaling pathway

Cell proliferation, tumor suppressor

$\mathrm{Ca}(2+)$ sensors in the process of vesicular trafficking and exocytosis
VP_393086

ExoCarta_10715

VP_10715

ExoCarta 13654

VP_1959

ExoCarta_4282

VP_4282

ExoCarta_107975

VP_107975

ExoCarta_5510

VP_5510

ExoCarta_338917

VP 338917

ExoCarta_4088

VP_4088

ExoCarta_6857

VP_6857

ExoCarta_976 ing processes early after leukocyte activation

Decreases mitochondrial Ca $(2+)$ uptake and reduces cytosolic $\mathrm{Ca}(2+)$ clearance after histamine stimulation

Cela3b Chymotrypsin-like elastase family, member $3 \mathrm{~B}$

Functions in the intestinal transport and metabolism of cholesterol

Little elastolytic activity

KDSR 3-ketodihydrosphingosine reductase

EMILIN3

Elastin microfibril interfacer 3

Catalyzes the reduction of 3-ketodihydrosphingosine to dihydrosphingosine

ExoCarta_79085

ExoCarta_67868

Developing gonads and osteogenic

VP_67868

ExoCarta_2531

VP_2531

ExoCarta_90187 mesenchyme

VP 90187

(


Table 1 (continued)

\begin{tabular}{|c|c|c|c|c|c|}
\hline \multirow[t]{2}{*}{ miRNA } & \multicolumn{2}{|c|}{ Predicted target mRNA } & \multirow[t]{2}{*}{ Function and detail } & \multicolumn{2}{|l|}{ Reference } \\
\hline & Symbol & Full name & & ExoCerta, Vesiclepidia & PMID \\
\hline \multicolumn{6}{|c|}{ (d) Predicted target genes for miRNa with increased expression on BM-H:BM,TM-H:TM and miRNA with decreased on AD-H:ADM } \\
\hline \multirow[t]{5}{*}{ miR-320e } & LAPTM4A & $\begin{array}{l}\text { Lysosomal protein transmembrane } 4 \\
\text { alpha }\end{array}$ & $\begin{array}{l}\text { Transport of small molecules across } \\
\text { endosomal and lysosomal mem- } \\
\text { branes. }\end{array}$ & $\begin{array}{l}\text { ExoCarta_9741 } \\
\text { VP_9741 }\end{array}$ & [57] \\
\hline & PNRC1 & $\begin{array}{l}\text { Proline-rich nuclear receptor coactiva- } \\
\text { tor } 1\end{array}$ & $\begin{array}{l}\text { RNA polymerase (pol) II-transcribed } \\
\text { genes by functioning as a nuclear } \\
\text { receptor coactivator }\end{array}$ & $\begin{array}{l}\text { ExoCarta_10957 } \\
V P_{-} 10957\end{array}$ & [50] \\
\hline & SKA3 & $\begin{array}{l}\text { Spindle and kinetochore associated } \\
\text { complex subunit } 3\end{array}$ & $\begin{array}{l}\text { Component of the spindle and } \\
\text { kinetochore-associated protein } \\
\text { complex that regulates microtubule } \\
\text { attachment to the kinetochores dur- } \\
\text { ing mitosis }\end{array}$ & VP_221150 & [46] \\
\hline & TMEM47 & Transmembrane protein 47 & $\begin{array}{l}\text { Localized to the ER and the plasma } \\
\text { membrane }\end{array}$ & $\begin{array}{l}\text { ExoCarta_83604 } \\
\text { VP_83604 }\end{array}$ & {$[58]$} \\
\hline & SEMA6D & $\begin{array}{l}\text { Sema domain, transmembrane domain } \\
\text { (TM), and cytoplasmic domain, (sema- } \\
\text { phorin) } 6 \mathrm{D}\end{array}$ & $\begin{array}{l}\text { Secreted and membrane associated } \\
\text { proteins } \\
\text { Axon pathfinding, fasciculation and } \\
\text { branching, and target selection }\end{array}$ & VP_80031 & [59] \\
\hline \multirow[t]{5}{*}{ miR-8075 } & TMOD2 & Tropomodulin 2 & $\begin{array}{l}\text { Actin-capping protein for the slow- } \\
\text { growing end of filamentous actin }\end{array}$ & $\begin{array}{l}\text { ExoCarta_29767 } \\
\text { VP_29767 }\end{array}$ & [22] \\
\hline & ADCY1 & Adenylate cyclase 1 & $\begin{array}{l}\text { Adenylate cyclase gene family that is } \\
\text { primarily expressed in the brain } \\
\mathrm{Ca}(2+) / \text { calmodulin concentration }\end{array}$ & $\begin{array}{l}\text { ExoCarta_107 } \\
\text { VP_107 }\end{array}$ & [48] \\
\hline & CD1B & CD1b molecule & $\begin{array}{l}\text { Primarily lipid and glycolipid antigens } \\
\text { of self or microbial origin to T cells }\end{array}$ & $\begin{array}{l}\text { ExoCarta_910 } \\
\text { VP_910 }\end{array}$ & {$[60,61]$} \\
\hline & OLFM1 & Olfactomedin 1 & $\begin{array}{l}\text { Neurogenesis, neural crest formation, } \\
\text { dorsal ventral patterning, cell-cell } \\
\text { adhesion } \\
\text { Cell cycle regulation, tumorigenesis, } \\
\text { and signaling pathways (Wnt, BMP) }\end{array}$ & VP_10439 & {$[62,63]$} \\
\hline & PRTG & Protogenin & $\begin{array}{l}\text { Development of various tissues, espe- } \\
\text { cially neurogenesis }\end{array}$ & VP_283659 & {$[46]$} \\
\hline \multirow[t]{5}{*}{ miR-6732-5p } & OAS2 & $\begin{array}{l}\text { 2'-5'-Oligoadenylate synthetase } 2, \\
69 / 71 \mathrm{kDa}\end{array}$ & $\begin{array}{l}\text { Innate immune response to viral infec- } \\
\text { tion }\end{array}$ & $\begin{array}{l}\text { ExoCarta_4939 } \\
\text { VP_4939 }\end{array}$ & [61] \\
\hline & STX17 & Syntaxin-17 & $\begin{array}{l}\text { Control of autophagosome membrane } \\
\text { fusion with the lysosome membrane }\end{array}$ & & [63] \\
\hline & KLK3 & Kallikrein related peptidase 3 & $\begin{array}{l}\text { GPCR signaling pathways, translation } \\
\text { Non-genomic (rapid) action of andro- } \\
\text { gen receptor. }\end{array}$ & VP_354 & [64] \\
\hline & DYNC1LI1 & $\begin{array}{l}\text { Dynein, cytoplasmic 1, light intermedi- } \\
\text { ate chain } 1\end{array}$ & Intracellular vesicle trafficking & ExoCarta_51143 & [65] \\
\hline & ABCC5 & $\begin{array}{l}\text { ATP-binding cassette, sub-family C } \\
\text { (CFTR/MRP), member } 5\end{array}$ & $\begin{array}{l}\text { Resistance to thiopurine anticancer } \\
\text { drugs, 6-mercaptopurine and thio- } \\
\text { guanine functions }\end{array}$ & $\begin{array}{l}\text { ExoCarta_10057 } \\
\text { VP_10057 }\end{array}$ & [66] \\
\hline
\end{tabular}


Table 1 (continued)

\begin{tabular}{|c|c|c|c|c|c|}
\hline \multirow[t]{2}{*}{ miRNA } & \multicolumn{2}{|c|}{ Predicted target mRNA } & \multirow[t]{2}{*}{ Function and detail } & \multicolumn{2}{|l|}{ Reference } \\
\hline & Symbol & Full name & & ExoCerta, Vesiclepidia & PMID \\
\hline \multirow[t]{5}{*}{ miR-2115-5p } & ATL3 & Atlastin GTPase 3 & $\begin{array}{l}\text { Network of interconnected tubules of } \\
\text { the endoplasmic reticulum }\end{array}$ & $\begin{array}{l}\text { ExoCarta_25923 } \\
\text { VP_25923 }\end{array}$ & [67] \\
\hline & USP49 & Ubiquitin specific peptidase 49 & $\begin{array}{l}\text { Epigenetic transcriptional activation } \\
\text { and acts as a regulator of mRNA } \\
\text { splicing. }\end{array}$ & $\begin{array}{l}\text { ExoCarta_25862 } \\
\text { VP-25,862 }\end{array}$ & [46] \\
\hline & TTPAL & Alpha tocopherol transfer protein like & $\begin{array}{l}\text { Stimulates the movement of vitamin } \\
\text { E between membrane vesicles } \\
\text { in vitro and facilitates the secretion of } \\
\text { tocopherol from hepatocytes }\end{array}$ & N/D (Not detected) & [68] \\
\hline & CERS6 & Ceramide synthase 6 & $\begin{array}{l}\text { Cell proliferation, differentiation, apop- } \\
\text { tosis, and senescence }\end{array}$ & $\begin{array}{l}\text { ExoCarta_253782 } \\
\text { VP_253782 }\end{array}$ & [69] \\
\hline & CD247 & CD247 molecule & $\begin{array}{l}\text { Encodes an immune inhibitory receptor } \\
\text { ligand that is expressed by hemat- } \\
\text { opoietic and non-hematopoietic cells, } \\
\text { such as T cells and B cells, and various } \\
\text { types of tumor cells }\end{array}$ & $\begin{array}{l}\text { ExoCarta_919 } \\
\text { VP_919 }\end{array}$ & [70] \\
\hline
\end{tabular}

were analyzed for POU class 3 homeobox 3 (POU3F3) [42], protocadherin alpha 2 (Pcdha2) [43], ceramide synthase 1 (CERS1) [44], early growth response (EGR) [45], and macrophage migration inhibitory factor $(M I F)$ [46]. miR-5787 was highly expressed in both $\mathrm{H}: \mathrm{BM}-$ $\mathrm{M}$ and H:T-M cells. The predicted mRNA was analyzed for phosphofurin acidic cluster sorting protein 1 (PACS1) [47], protein phosphatase 1 regulatory subunit 7 (PPP1R7) [48], visual system homeobox 2 (VSX2) [49], SMAD family member 2, SMAD family member 3 [50], and synaptotagmin 1 (SYT1) [51]. In addition, miR-6732-5p, miR-8075, miR-320e, and miR-2115-5p expression decreased in the $\mathrm{H}: \mathrm{AD}-\mathrm{M}$ group and increased in the H:BM-M and H:T-M groups (Fig. 8). Interestingly, miR-638, which significantly reduced $T N F-\alpha, C O X-2, I L-1 \beta$, and $I L-6$ (Fig. 4) expression, showed increased expression only in H:BM-M. One of the predicted mRNAs analyzed Solute carrier family 25-member 23 (SLC25A23) and Adhesion G proteincoupled receptor E5 (ADGRE5) was reported to be involved in both adhesion and signaling processes [45]. $S L C 25 A 23$ reportedly decreases mitochondrial $\mathrm{Ca}(2+)$ uptake and reduces cytosolic $\mathrm{Ca}(2+)$ clearance after histamine stimulation [51]. In addition, approximately 100 predicted mRNAs were analyzed, and we tried to select the most related proteins through gene ontology analysis. We hypothesized that miR-638-related protein inhibited the increase in inflammatory factors in HMEECs; therefore, we predicted that it was APBA2 (Fig. 7c). It is cautious to predict proteins that have organic relationships in cells, but we found that $A P B A 2$ can play a role in binding and transmitting factors related to binding to membranes containing immunity and differentiation [36]. APBA2 encodes a cell surface receptor and transmembrane precursor protein that is cleaved by secretases to form a number of peptides. In addition, two of these peptides are antimicrobial peptides, which have been shown to have bactericidal and antifungal activities. Mutations in this gene are associated with autosomal dominant Alzheimer's disease and cerebral arterial amyloidosis (cerebral amyloid angiopathy). Several transcriptome variants have been discovered that encode several different isotypes of this gene [52]. As reported for EVs to communicate between cells, a major difference among vesicle subtypes is their origin, while microvesicles and ectosomes bud from the plasma membrane, EV formation begins on early endosomes [6, 7]. After maturation in multivesicular bodies through the invagination of the endosomal membrane and formation of intraluminal vesicles (ILVs), EVs are released by the fusion of ILVs with the plasma membrane [14]. The specific proteins incorporated into ILVs are regulated mainly by the endosomalsorting complex required for transport (ESCRT), of which there are four: ESCRT-0, I, II, and III. As a result, we discussed that binding proteins, such as $A P B A 2$, can induce and stimulate the transport of inflammatory factors by connecting the cellular membrane. In a study that reported the activity of $A P B A 2$, it was reported in patients with age-related macular degeneration (AMD), and autophagy factors were identified by treating ARPE-19 cells with soluble amyloid with an oligomer [53]. Autophagy activated in ARPE-19 cells treated with $A P B A 2$ altered the expression pattern of 


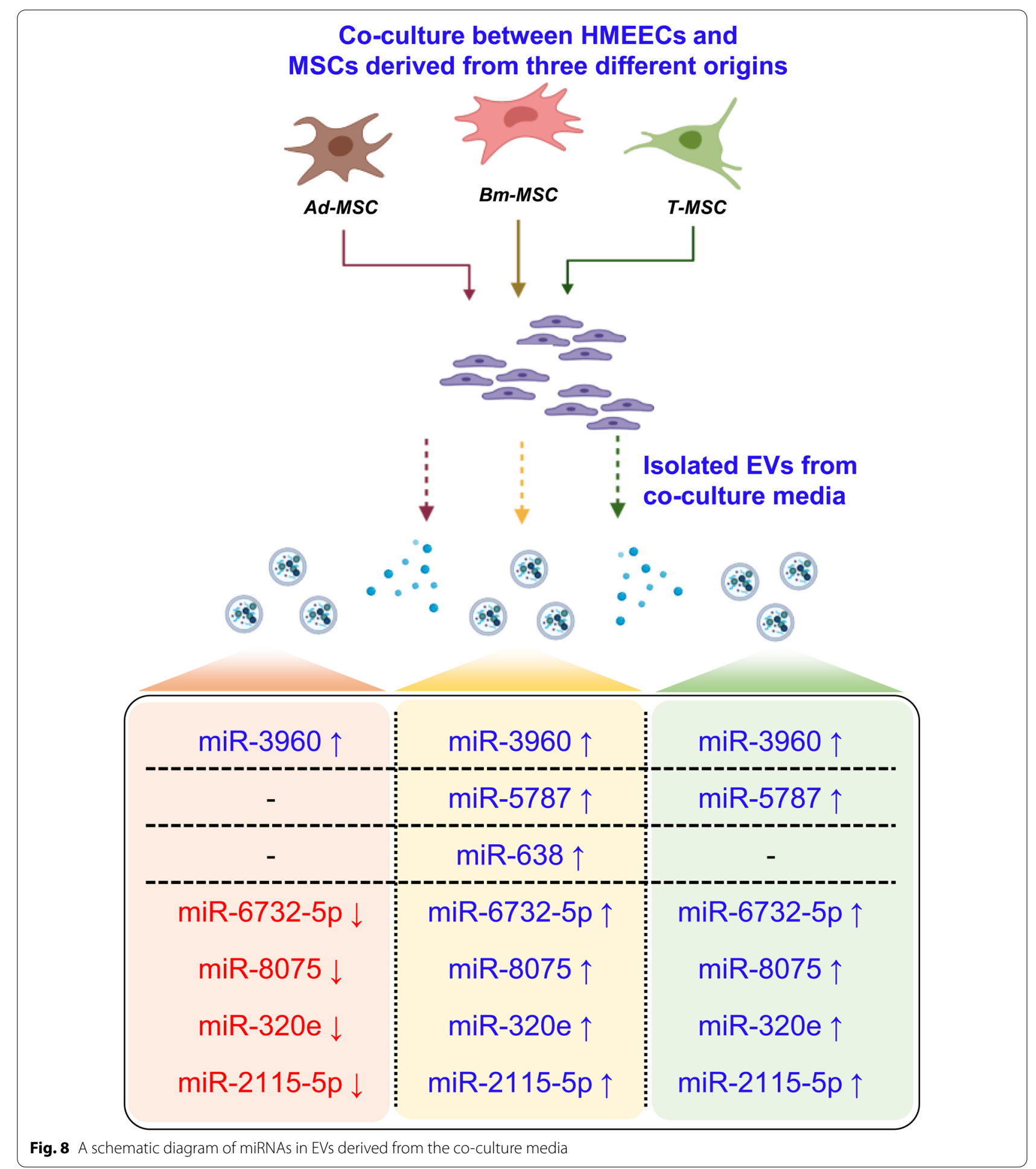

LC3 by creating a phagocytic compartment and activating p62, thus clarifying the potential ambiguity mechanism of retinal cells. It has been reported that $A P B A 2$ is involved in the MAPK signaling pathway and it alters cell viability, migration, and invasion [52]. However, the relationship between amyloid activity and neuroinflammation has been reported [54]; the role of inflammation in auditory hearing loss relief should be explored in further studies. 
MSCs were extracted from three tissues and the changes in miRNA payload in EVs and the anti-inflammatory effect of MSC-derived EVs were analyzed in this study. In particular, to improve the anti-inflammatory effect of epithelial cells that induce inflammation, EVs of epithelial cells and MSC co-culture medium were extracted, and the payload was confirmed to change. This study was conducted based on the essential meaning of EV as an intercellular messenger to confirm the payload of HMEEC-derived EV and MSC-derived EV. We believed that the EVs derived from co-cultured media generated containing new molecules by the cell-to-cell communication process, so EVs in a single culture medium was used as controls. The payload in the EVs showed significantly different when co-culture between HMEEC and MSCs in Fig. 5. However, it was not possible to prove the factors expressed from different cell line in the single culture medium, we tried to explain reflecting the biological characteristics of EV for future studies. We discussed that the mechanism of cross-talk between different cell lines makes it possible to express unique biomarkers. Our study predicts that the change in the payload in EVs expressed by co-culture with stem cells can be used in various disease models. Therefore, the co-culture of stem cells into donor and recipient cells lead to the expression of new factors, which could prove valuable in the field of regenerative medicine and material development.

\section{Acknowledgements}

This work was supported by the Korea Health Technology R\&D Project through the Korea Health Industry Development Institute (KHIDI) under Grant HI19C1334; and supported by Basic Science Research Program through the National Research Foundation of Korea(NRF) funded by the Ministry of Education (Grant: 2021R1I1A1A01040273). This work also supported by the National Research Foundation of Korea (NRF) funded by the Korean government (MIST) under Grant NRF-2020R1A2C1009789.

\section{Authors' contributions}

DJP. designed and analyzed the entire study of extracellular vesicles through a co-culture approach between MSCs and HMEECs. JEP. and THK analyzed biological method and technical support. YJS provided support for this study. DJP wrote the first draft of manuscript, and all the authors have reviewed the manuscript. All authors read and approved the final manuscript.

\section{Funding}

This study was funded by the National Research Foundation of Korea (NRF) grant funded by the Korea government (MSIT) (No. NRF-2020R1 A2C1009789).

\section{Availability of data and materials}

Not applicable.

\section{Declarations}

\section{Ethics approval and consent to participate}

The human adipose tissue, bone marrow, and tonsils were obtained from the iliac crest of patients who received transplantation treatment at the Wonju Severance Christian Hospital after obtaining their written consent (IRB number: CR320104).
Consent for publication

Not applicable.

\section{Competing interests}

The authors declare that they have no competing interests.

\section{Author details}

${ }^{1}$ Department of Otorhinolaryngology, Yonsei University Wonju College of Medicine, 20 Ilsan- ro, Wonju, Gangwon-do 26426, South Korea. ${ }^{2}$ Research Institute of Hearing Enhancement, Wonju, Gangwon-do 26426, South Korea. ${ }^{3}$ Department of Surgery, University of California San Diego, 212 Dickinson Street, MC 8236, San Diego, CA 92103, USA. ${ }^{4}$ School of Pharmacy and Biomedical Sciences, Curtin University, Bentley, WA 6102, Australia.

Received: 3 March 2021 Accepted: 8 May 2021

Published online: 20 May 2021

\section{References}

1. Sugino H, Tsumura S, Kunimoto M, Noda M, Chikuie D, Noda C, et al. Influence of pneumococcal conjugate vaccine on acute otitis media with severe middle ear inflammation: A retrospective multicenter study. PLoS ONE. 2015;10:e0137546. https://doi.org/10.1371/journal.pone.0137546.

2. Lighthall JG, Kempton JB, Hausman F, MacArthur CJ, Trune DR. Control of middle ear inflammatory and ion homeostasis genes by transtympanic glucocorticoid and mineralocorticoid treatments. PLOS ONE. 2015;10:e0119228. https://doi.org/10.1371/journal.pone.0119228.

3. Sessa R, Hata A. Role of microRNAs in lung development and pulmonary diseases. Pulm Circ. 2013;3:315-28. https://doi.org/10.4103/2045-8932. 114758.

4. Gowen A, Shahjin F, Chand S, Odegaard KE, Yelamanchili SV. Mesenchymal stem cell-derived extracellular vesicles: challenges in clinical applications. Front Cell Dev Biol. 2020;8:149. https://doi.org/10.3389/fcell.2020. 00149.

5. Joo HS, Suh JH, Lee HJ, Bang ES, Lee JM. Current knowledge and future perspectives on mesenchymal stem cell-derived exosomes as a new therapeutic agent. Int J Mol Sci. 2020. https://doi.org/10.3390/ijms210307 27.

6. Xiao YW, Zhong JN, Zhong BY, Huang JY, Jiang LX, Jiang Y, et al. Exosomes as potential sources of biomarkers in colorectal cancer. Cancer Lett. 2020;476:13-22. https://doi.org/10.1016/j.canlet.2020.01.033.

7. Jeppesen DK, Fenix AM, Franklin JL, Higginbotham JN, Zhang Q, Zimmerman $L$, et al. Reassessment of exosome composition. Cell 2019;177:42845. https://doi.org/10.1016/j.cell.2019.02.029.

8. Shenoy GN, Bhatta M, Loyall JL, Kelleher RJ Jr, Bernstein JM, Bankert RB. Exosomes represent an immune suppressive T cell checkpoint in human chronic inflammatory microenvironments. Immunol Invest. 2020;49:72643. https://doi.org/10.1080/08820139.2020.1748047.

9. Chiba M, Kimura M, Asari S. Exosomes secreted from human colorectal cancer cell lines contain mRNAs, microRNAs and natural antisense RNAs, that can transfer into the human hepatoma HepG2 and lung cancer A549 cell lines. Oncol Rep. 2012;28:1551-8. https://doi.org/10.3892/or. 2012.1967.

10. Preciado S, Muntion S, Sanchez-Guijo F. Improving hematopoietic engraftment: Potential role of mesenchymal stromal cell-derived extracellular vesicles. Stem Cells. 2021;39:26-32. https://doi.org/10.1002/stem. 3278.

11. Buratta S, Tancini B, Sagini K, Delo F, Chiaradia E, Urbanelli L, et al. Lysosomal exocytosis, exosome release and secretory autophagy: The autophagic- and endo-lysosomal systems go extracellular. Int J Mol Sci. 2020;21:2576. https://doi.org/10.3390/ijms21072576.

12. Cheng $Q, L i X$, Wang Y, Dong M, Zhan FH, Liu J. The ceramide pathway is involved in the survival, apoptosis and exosome functions of human multiple myeloma cells in vitro. Acta Pharmacol Sin. 2018;39:561-8. https:// doi.org/10.1038/aps.2017.118.

13. Park DJ, Yun WS, Kim WC, Park JE, Lee SH, Ha S, et al. Improvement of stem cell-derived exosome release efficiency by surface-modified nanoparticles. J Nanobiotechnol. 2020;18:178. https://doi.org/10.1186/ s12951-020-00739-7. 
14. Kalluri R, LeBleu VS. The biology, function, and biomedical applications of exosomes. Science (1979). 2020;367:eaau6977. https://doi.org/10. 1126/science.aau6977.

15. Maas SLN, Breakefield XO, Weaver AM. Extracellular vesicles: unique intercellular delivery vehicles. Trends Cell Biol. 2017;27:172-88. https:// doi.org/10.1016/j.tcb.2016.11.003.

16. Pisano S, Pierini I, Gu JH, Gazze A, Francis LW, Gonzalez D, et al. Immune (cell) derived exosome mimetics (IDEM) as a treatment for ovarian cancer. Front Cell Dev Biol. 2020;8:553576. https://doi.org/10.3389/fcell. 2020.553576.

17. Atai NA, Balaj L, van Veen $H$, Breakefield XO, Jarzyna PA, Van Noorden CJF, et al. Heparin blocks transfer of extracellular vesicles between donor and recipient cells. J Neurooncol. 2013;115:343-51. https://doi. org/10.1007/s11060-013-1235-y.

18. Cho BS, Kim JO, Ha DH, Yi YW. Exosomes derived from human adipose tissue-derived mesenchymal stem cells alleviate atopic dermatitis. Stem Cell Res Ther. 2018;9:187. https://doi.org/10.1186/ s13287-018-0939-5.

19. Lee KE, Jung SA, Joo YH, Song EM, Moon CM, Kim SE, et al. The efficacy of conditioned medium released by tonsil-derived mesenchymal stem cells in a chronic murine colitis model. PLoS ONE. 2019;14:e0225739. https://doi.org/10.1371/journal.pone.0225739.

20. Zhou Y, Zhou W, Chen X, Wang Q, Li C, Chen Q, et al. Bone marrow mesenchymal stem cells-derived exosomes for penetrating and targeted chemotherapy of pancreatic cancer. Acta Pharm Sin B. 2020;10:1563-75. https://doi.org/10.1016/j.apsb.2019.11.013.

21. Kulkarni B, Gondaliya P, Kirave P, Rawal R, Jain A, Garg R, et al. Exosomemediated delivery of miR-30a sensitize cisplatin-resistant variant of oral squamous carcinoma cells via modulating Beclin 1 and BCl2. Oncotarget. 2020;11:1832-45. https://doi.org/10.18632/oncotarget.27557.

22. Liang B, Peng P, Chen S, Li L, Zhang M, Cao D, et al. Characterization and proteomic analysis of ovarian cancer-derived exosomes. J Proteomics. 2013;80:171-82. https://doi.org/10.1016/j.jprot.2012.12.029.

23. Joshi BS, de Beer MA, Giepmans BG, Zuhorn IS. Endocytosis of extracellular vesicles and release of their cargo from endosomes. ACS Nano. 2020;14:4444-55. https://doi.org/10.1021/acsnano.9b10033.

24. Qin S, Dorschner RA, Masini I, Lavoie-Gagne O, Stahl PD, Costantini TW, et al. TBC1D3 regulates the payload and biological activity of extracellular vesicles that mediate tissue repair. FASEB J. 2019;33:6129-39. https://doi.org/10.1096/f.201802388R.

25. Ambattu LA, Ramesan S, Dekiwadia C, Hanssen E, Li H, Yeo LY. High frequency acoustic cell stimulation promotes exosome generation regulated by a calcium-dependent mechanism. Commun Biol. 2020;3:553. https://doi.org/10.1038/s42003-020-01277-6.

26. Seo YJ, Choi JY. Expression and localization of aquaporin water channels in human middle ear epithelium. Otol Neurotol. 2015;36:1284-9. https://doi.org/10.1097/MAO.0000000000000797.

27. Bacic A, Prgomet D, Janjanin S. Tonsil-derived mesenchymal stem cells exert immunosuppressive effects on T cells. Croat Med J. 2019;60:12-9. https://doi.org/10.3325/cmj.2019.60.12.

28. Dominici M, Le Blanc K, Mueller I, Slaper-Cortenbach I, Marini F, Krause $D$, et al. Minimal criteria for defining multipotent mesenchymal stromal cells. The International Society for Cellular Therapy position statement. Cytotherapy. 2006;8:315-7. https://doi.org/10.1080/146532406008559 05 .

29. Chun YM, Moon SK, Lee HY, Webster P, Brackmann DE, Rhim JS, et al. Immortalization of normal adult human middle ear epithelial cells using a retrovirus containing the E6/E7 genes of human papillomavirus type 16. Ann Otol Rhinol Laryngol. 2002;111:507-17. https://doi.org/10.1177/ 000348940211100606.

30. Thery C, Witwer KW, Aikawa E, Alcaraz MJ, Anderson JD, Andriantsitohaina $\mathrm{R}$, et al. Minimal information for studies of extracellular vesicles 2018 (MISEV2018): a position statement of the International Society for Extracellular Vesicles and update of the MISEV2014 guidelines. J Extracell Vesicles. 2018;7:1535750. https://doi.org/10.1080/20013078.2018.15357 50

31. Lu K, Li HY, Yang K, Wu JL, Cai XW, Zhou Y, et al. Exosomes as potential alternatives to stem cell therapy for intervertebral disc degeneration: in-vitro study on exosomes in interaction of nucleus pulposus cells and bone marrow mesenchymal stem cells. Stem Cell Res Ther. 2017;8:108. https://doi.org/10.1186/s13287-017-0563-9.
32. Bruno $S$, Porta $S$, Bussolati B. Extracellular vesicles in renal tissue damage and regeneration. Eur J Pharmacol. 2016;790:83-91. https://doi.org/10. 1016/j.jphar.2016.06.058.

33. Danzer KM, Kranich LR, Ruf WP, Cagsal-Getkin O, Winslow AR, Zhu L, et al. Exosomal cell-to-cell transmission of alpha synuclein oligomers. Mol Neurodegener. 2012;7:42. https://doi.org/10.1186/1750-1326-7-42.

34. Shimasaki T, Yamamoto $S$, Arisawa T. Exosome research and co-culture study. Biol Pharm Bull. 2018;41:1311-21. https://doi.org/10.1248/bpb. b18-00223.

35. Lee JH, Lau KF, Perkinton MS, Standen CL, Shemilt SJ, Mercken L, et al. The neuronal adaptor protein $\mathrm{X} 11$ alpha reduces Abeta levels in the brains of Alzheimer's APPswe Tg2576 transgenic mice. J Biol Chem. 2003;278:47025-9. https://doi.org/10.1074/jbc.M300503200.

36. Becot A, Volgers C, van Niel G. Transmissible endosomal intoxication: a balance between exosomes and lysosomes at the basis of intercellular amyloid propagation. Biomedicines. 2020;8:272. https://doi.org/10.3390/ biomedicines 8080272.

37. Borgovan T, Crawford L, Nwizu C, Quesenberry P. Stem cells and extracellular vesicles: biological regulators of physiology and disease. Am J Physiol Cell Physiol. 2019;317:C155-C66. https://doi.org/10.1152/ajpcell. 00017.2019.

38. Eirin A, Riester SM, Zhu XY, Tang H, Evans JM, O'Brien D, et al. MicroRNA and mRNA cargo of extracellular vesicles from porcine adipose tissuederived mesenchymal stem cells. Gene. 2014;551:55-64. https://doi.org/ 10.1016/j.gene.2014.08.041

39. Ting PJ, Lin CH, Huang FL, Lin MC, Hwang KP, Huang YC, et al. Epidemiology of acute otitis media among young children: a multiple database study in Taiwan. J Microbiol Immunol Infect. 2012;45:453-8. https://doi. org/10.1016/j.jmii.2012.06.007.

40. Kakiuchi M, Tsujigiwa H, Orita Y, Nagatsuka H, Yoshinobu J, Kariya S, et al. Cyclooxygenase 2 expression in otitis media with effusion. Am J Otolaryngol. 2006;27:81-5. https://doi.org/10.1016/j.amjoto.2005.07.009.

41. Pichichero ME. Helping children with hearing loss from otitis media with effusion. Lancet. 2018;392:533-4. https://doi.org/10.1016/S0140-6736(18) 31862-2.

42. Yang J, Meng X, Yu Y, Pan L, Zheng Q, Lin W. LncRNA POU3F3 promotes proliferation and inhibits apoptosis of cancer cells in triple-negative breast cancer by inactivating caspase 9. Biosci Biotechnol Biochem. 2019;83:1117-23. https://doi.org/10.1111/cpr.12966.

43. Carayon K, Chaoui K, Ronzier E, Lazar I, Bertrand-Michel J, Roques V, et al. Proteolipidic composition of exosomes changes during reticulocyte maturation. J Biol Chem. 2011;286:34426-39. https://doi.org/10.1074/jbc. M111.257444.

44. Fan XL, Zhang Y, Li X, Fu QL. Mechanisms underlying the protective effects of mesenchymal stem cell-based therapy. Cell Mol Life Sci. 2020;77:2771-94. https://doi.org/10.1007/s00018-020-03454-6.

45. Pio R, Jia ZY, Baron VT, Mercola D, UCI NCI SPECS Consortium Strategic. Early growth response 3 (Egr3) is highly over-expressed in non-relapsing prostate cancer but not in relapsing prostate cancer. PLoS ONE. 2013;8:e54096. https://doi.org/10.1371/journal.pone.0054096.

46. Buschow SI, van Balkom BW, Aalberts M, Heck AJ, Wauben M, Stoorvogel W. MHC class II-associated proteins in B-cell exosomes and potential functional implications for exosome biogenesis. Immunol Cell Biol. 2010;88:851-6. https://doi.org/10.1038/icb.2010.64.

47. Valadi H, Ekstrom K, Bossios A, Sjostrand M, Lee JJ, Lotvall JO. Exosomemediated transfer of mRNAs and microRNAs is a novel mechanism of genetic exchange between cells. Nat Cell Biol. 2007;9:654-U72. https:// doi.org/10.1038/ncb1596.

48. Gonzales PA, Pisitkun T, Hoffert JD, Tchapyjnikov D, Star RA, Kleta R, et al. Large-scale proteomics and phosphoproteomics of urinary exosomes. J Am Soc Nephrol. 2009;20:363-79. https://doi.org/10.1681/ASN.20080 40406.

49. Moon PG, Lee JE, You S, Kim TK, Cho JH, Kim IS, et al. Proteomic analysis of urinary exosomes from patients of early IgA nephropathy and thin basement membrane nephropathy. Proteomics. 2011;11:2459-75. https://doi. org/10.1002/pmic.201000443.

50. He M, Qin H, Poon TC, Sze SC, Ding X, Co NN, et al. Hepatocellular carcinoma-derived exosomes promote motility of immortalized hepatocyte through transfer of oncogenic proteins and RNAs. Carcinogenesis. 2015;36:1008-18. https://doi.org/10.1093/carcin/bgv081. 
51. Coppola T, Magnin-Luthi S, Perret-Menoud V, Gattesco S, Schiavo G, Regazzi R. Direct interaction of the Rab3 effector RIM with Ca2 + channels, SNAP-25, and synaptotagmin. J Biol Chem. 2001;276:32756-62. https://doi.org/10.1074/jbc.M100929200.

52. Xu J, Ying Y, Xiong G, Lai L, Wang Q, Yang Y. Amyloid beta precursor protein silencing attenuates epithelialmesenchymal transition of nasopharyngeal carcinoma cells via inhibition of the MAPK pathway. Mol Med Rep. 2019;20:409-16. https://doi.org/10.3892/mmr.2019.10293.

53. Feng $L$, Liao $X$, Zhang $Y$, Wang F. Protective effects on age-related macular degeneration by activated autophagy induced by amyloid-beta in retinal pigment epithelial cells. Discov Med. 2019;27:153-60.

54. Ismail R, Parbo P, Madsen LS, Hansen AK, Hansen KV, Schaldemose JL, et al. The relationships between neuroinflammation, beta-amyloid and tau deposition in Alzheimer's disease: a longitudinal PET study. J Neuroinflamm. 2020;17:151. https://doi.org/10.1186/s12974-020-01820-6.

55. Kowal J, Arras G, Colombo M, Jouve M, Morath JP, Primdal-Bengtson B, et al. Proteomic comparison defines novel markers to characterize heterogeneous populations of extracellular vesicle subtypes. Proc Natl Acad Sci USA. 2016;113:E968-77. https://doi.org/10.1073/pnas.1521230113.

56. Schiavinato A, Becker AK, Zanetti M, Corallo D, Milanetto M, Bizzotto D, et al. EMILIN-3, peculiar member of elastin microfibril interface-located protein (EMILIN) family, has distinct expression pattern, forms oligomeric assemblies, and serves as transforming growth factor beta (TGF-beta) antagonist. J Biol Chem. 2012;287:11498-515. https://doi.org/10.1074/ jbc.M111.303578.

57. van Herwijnen MJ, Zonneveld MI, Goerdayal S, Nolte-'t Hoen EN, Garssen J, Stahl B, et al. Comprehensive proteomic analysis of human milk-derived extracellular vesicles unveils a novel functional proteome distinct from other milk components. Mol Cell Proteomics. 2016;15:3412-23. https:// doi.org/10.1074/mcp.M116.060426.

58. Lai RC, Tan SS, Teh BJ, Sze SK, Arslan F, de Kleijn DP, et al. Proteolytic potential of the MSC exosome proteome: Implications for an exosomemediated delivery of therapeutic proteasome. Int J Proteomics. 2012;2012:971907. https://doi.org/10.1155/2012/971907.

59. O'Connor BP, Eun SY, Ye Z, Zozulya AL, Lich JD, Moore CB, et al. Semaphorin $6 \mathrm{D}$ regulates the late phase of $C D 4+T$ cell primary immune responses. Proc Natl Acad Sci USA. 2008;105:13015-20. https://doi.org/10. 1073/pnas.0803386105.

60. Gadola SD, Zaccai NR, Harlos K, Shepherd D, Castro-Palomino JC, Ritter $\mathrm{G}$, et al. Structure of human CD1b with bound ligands at 2.3 angstrom, a maze for alkyl chains. Nat Immunol. 2002;3:721-6. https://doi.org/10. $1038 /$ ni821.
61. Skogberg G, Gudmundsdottir J, van der Post S, Sandstrom K, Bruhn S, Benson $M$, et al. Characterization of human thymic exosomes. PLoS ONE. 2013;8:e67554. https://doi.org/10.1371/journal.pone.0067554.

62. Harris EA, Stephens KK, Winuthayanon W. Extracellular vesicles and the oviduct function. Int J Mol Sci. 2020;21:8280. https://doi.org/10.3390/ ijms21218280.

63. Vats S, Manjithaya R. A reversible autophagy inhibitor blocks autophagosome-lysosome fusion by preventing Stx17 loading onto autophagosomes. Mol Biol Cell. 2019;30:2283-95. https://doi.org/10.1091/mbc. E18-08-0482.

64. Stefanini AC, da Cunha BR, Henrique T, Tajara EH. Involvement of kallikrein-related peptidases in normal and pathologic processes. Dis Markers. 2015;2015:946572. https://doi.org/10.1155/2015/946572.

65. Yoder JH, Han M. Cytoplasmic dynein light intermediate chain is required for discrete aspects of mitosis in Caenorhabditis elegans. Mol Biol Cell. 2001;12:2921-33. https://doi.org/10.1091/mbc.12.10.2921.

66. Jansen RS, Mahakena S, de Haas M, Borst P, van de Wetering K. ATPbinding cassette subfamily $C$ member 5 (ABCC5) functions as an efflux transporter of glutamate conjugates and analogs. J Biol Chem. 2015;290:30429-40. https://doi.org/10.1074/jbc.M115.692103.

67. Rismanchi N, Soderblom C, Stadler J, Zhu PP, Blackstone C. Atlastin GTPases are required for Golgi apparatus and ER morphogenesis. Hum Mol Genet. 2008;17:1591-604. https://doi.org/10.1093/hmg/ddn046.

68. Miller GW, Ulatowski L, Labut EM, Lebold KM, Manor D, Atkinson J, et al. The a-tocopherol transfer protein is essential for vertebrate embryogenesis. PLOS ONE. 2012;7:e47402. https://doi.org/10.1371/journal.pone.00474 02.

69. Verlekar D, Wei SJ, Cho H, Yang S, Kang MH. Ceramide synthase-6 confers resistance to chemotherapy by binding to CD95/Fas in T-cell acute lymphoblastic leukemia. Cell Death Dis. 2018;9:925. https://doi.org/10. 1038/s41419-018-0964-4.

70. Blanchard N, Lankar D, Faure F, Regnault A, Dumont C, Raposo G, et al. TCR activation of human T cells induces the production of exosomes bearing the TCR/CD3/zeta complex. J Immunol. 2002;168:3235-41. https://doi.org/10.4049/jimmunol.168.7.3235.

\section{Publisher's Note}

Springer Nature remains neutral with regard to jurisdictional claims in published maps and institutional affiliations.
Ready to submit your research? Choose BMC and benefit from:

- fast, convenient online submission

- thorough peer review by experienced researchers in your field

- rapid publication on acceptance

- support for research data, including large and complex data types

- gold Open Access which fosters wider collaboration and increased citations

- maximum visibility for your research: over 100M website views per year

At BMC, research is always in progress.

Learn more biomedcentral.com/submissions 